Deniz, K. ve Keray Dinçel, B. (2019). Türkçe öğretmenlerinin anlama becerilerinde ölçme ve değerlendirmeye yönelik görüşleri. Ana Dili Eğitimi Dergisi, 7(1), 28-64.

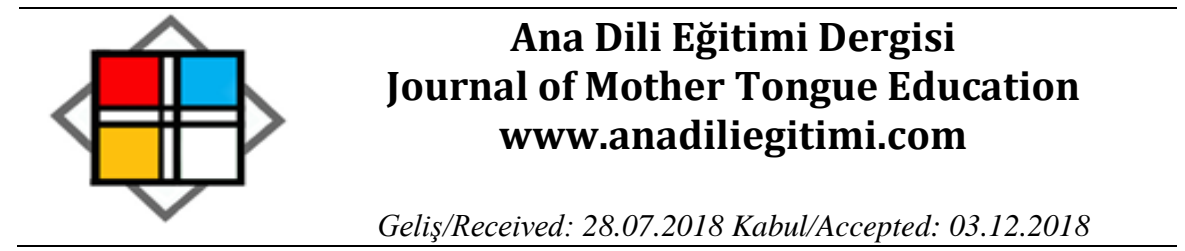

\title{
Türkçe Öğretmenlerinin Anlama Becerilerinde Ölçme ve Değerlendirmeye Yönelik Görüşleri*
}

\author{
Kemalettin DENIZ** \\ Betül KERAY DINÇEL ${ }^{* * *}$
}

\begin{abstract}
Öz
Bu araştırmanın amacl; Türkçe öğretmenlerinin Türkçe eğitiminin, okuma becerisinin, dinleme/izleme becerisinin ölçme ve değerlendirmesine ilişkin görüşlerini belirlemektir. Araştırma nitel bir çalışmadır. Çalışma grubu olarak ön uygulamada 5 , ana uygulamada 50 öğretmenden görüş alınmışıı. Veri toplama aracı olarak yarı yapılandırılmış görüşme formu kullanılmıştır. Görüşme formunda 23 soru yer almaktadır. İçerik analizi yöntemi kullanılarak veriler incelenmiştir. Türkçe öğretmenlerinin Türkçe eğitimi, okuma ve dinleme becerilerinin ölçme ve değerlendirmesine ilişkin görüşleri incelendiğinde genellikle ölçme ve değerlendirme kavramını bilmedikleri, ölçme ve değerlendirmeyi ağılıklı olarak sürecin sonunda kullandıkları, Türkçe Dersi Öğretim Programı $(5,6$, 7 ve 8. sınıflar) ve kitaplardaki ölçme ve değerlendirme araçlarını çoğunun kullanmadığı, öğrenme alanlarına göre ayrı ayrı puanlama yapmadıkları, anlama becerilerinin ölçümüne yönelik başta açık uçlu ve kısa cevaplı olmak üzere aynı soru türlerini kullandıkları, özellikle sınıfların kalabalık olması gibi pek çok sorun belirttikleri ortaya çıkmıştır.
\end{abstract}

Anahtar Kelimeler: Ölçme ve değerlendirme, ölçme araçları, anlama becerileri, okuma, dinleme/izleme, Türkçe Eğitimi.

\section{Turkish Language Teachers' Opinions about the Assessment and Evaluation of Comprehension Skills}

\begin{abstract}
The purpose of the study was to investigate the opinions of Turkish language arts teachers about the assessment and evaluation of Turkish language arts teaching, reading skill and listening/monitoring skill. The current study is a qualitative study. A semi-structured interview protocol was used as a data collection tool. In the piloting of the interview protocol, 5 Turkish language arts teachers were involved and then the interview form was administered to 50 Turkish language arts teachers. In the interview form, there are 23 questions. The collected data were analyzed through content analysis. The findings related to the assessment and evaluation in the dimension of Turkish language arts teaching, reading and listening/monitoring skill revealed that most of the participants do not know the concepts of assessment and evaluation, they mostly use assessment and evaluation at the end of the process, most of them do not make use of the assessment and evaluation tools provided in Turkish Language Arts Curriculum $\left(5,6,7\right.$ and $8^{\text {th }}$ grades) and the textbooks, they used the same types of questions, mainly open-ended and short-
\end{abstract}

\footnotetext{
* Doç. Dr. Kemalettin Deniz danışmanlığında hazırlanan aynı adlı doktora tezinden üretilmiştir.

** Doç. Dr., Gazi Üniversitesi, Gazi Eğitim Fakültesi, Türkçe Eğitimi ABD, Ankara, kemalettindeniz@hotmail.com, ORCID: 0000-0001-7531-490X

*** Dr. Öğretim Üyesi, Aksaray Üniversitesi, Eğitim Fakültesi, Türkçe Eğitimi ABD, Aksaray, betulkeraydincel@gmail.com, ORCID: 0000-0002-2184-7361
} 
answer, to measure their comprehension skills, especially when the class indicated a lot of problems such as crowdedness.

Keywords: Assessment and evaluation, evaluation tools, comprehension skills, reading, listening/monitoring, Turkish language education.

\section{Giriş}

Anlama becerilerinden biri olan dinleme/izleme becerisi, işitilenlerin zihin tarafından anlamlandırılmasıyla gerçekleşen bir süreçtir. Dinleme/izleme bireyin ilk kazandığı beceri olduğu gibi iletişim ve öğrenmenin de temel ögesidir. Anlama becerilerinden bir diğeri olan okuma becerisi gözle görülen basılı veya görsel bir iletiden zihnin yardımıyla anlam çıkarma sürecidir.

Eğitim öğretim sürecinin dolayısıyla da anlama becerilerinin gelişiminin bir parçası ölçme ve değerlendirmedir. "Ölçme, eğitim kararlarının verilmesinde güvenilir ve geçerli bilgi sağlamada işe koşulur. Değerlendirme ise, kendisi de dâhil olmak üzere, eğitim sistemindeki ögelerin iyi işleyip işlemediğini, varsa işlemeyen yönleri ortaya koyar; böylece sistemin onarılmasını sağlar" (Baykul, 2010: 97).

Anlama becerilerinden okuduğunu anlamanın değerlendirilmesi, bir 20. yüzyıl olgusu olmasına rağmen okullar, okunması istenen metinler, onları okuması gereken öğrenciler ve öğrencilerin bunları anlayıp anlamadıklarını bilmek isteyen veya bilmeye ihtiyacı olan öğretmenler var olduğundan beri sınıf uygulamalarının bir parçasıdır. Bir öğretmen tarafından verilen her ödev, her kitap raporu veya bölüm özeti ve bir kitap, hikâye, makale veya bölüm hakkında gerçekleştirilen her konuşma değerlendirme için bir fırsat sunmaktadır. Ancak, 20. yüzyıla kadar bu fırsatlar yeterince kullanılamamaktaydı. Okuma başarısının bir göstergesi olarak okuduğunu anlamanın nispeten daha geç devreye girmiş olmasının iki mantıklı açıklaması vardır. Illk olarak, okuma becerisinin 17. yüzyıldan 19. yüzyıla kadar göstergesi sözlü ifade etme kapasitesiydi. Bunun temel belirleyicisi doğruluk veya ifade gücündeki akıcılıktı. Íkinci olarak, kilise ile bağlantılı çevrelerde en azından kişisel olarak anlama manasında okuduğunu anlama değerli bulunan bir şey değildi, değerli olmasını sağlayabilecek tek şey ise onun değer verilen metin ezberleme yetisine giden yolda bir basamak olmasıydı (Pearson ve Hamm, 2005: 15).

Son yirmi yıldaki okuma araştırmaları ve kuramlarından ortaya çıkmış olan ilkeler, değerlendirme ile öğretim arasında yakın bir bağ olduğunu kabul etmektedirler; yani, değerlendirmenin öğretimin bir parçası olduğunu. Bu ilkeler şunları önermektedir:

1. Değerlendirmeler oluşturulurken veya yorumlanırken, okuyucuyu, metni ve bağlamı dikkate almalıdır.

2. İzole edici becerilerden ziyade birleştirici becerilere odaklanılmalıdır.

3. Okuma statik bir ürün olmaktan ziyade dinamik bir süreç olarak görülmelidir. 
4. Öğrenci öğretmen etkileşimlerini göz ardı eden değil destekleyen teknikler geliştirilmelidir.

5. Okuduğunu anlamanın çeşitli ölçümleri kullanılmalıdır (Valencia ve Pearson, 1988).

Okuma etkinliklerinin ölçme ve değerlendirilmesi formal ve informal değerlendirmeler şeklindedir. Okuma öncesi, sırası ve sonrasında değerlendirme yapılacağı gibi genel bir değerlendirme de yapılabilir. Yapılan ölçme ve değerlendirmeler öğretimi yönlendirdiği gibi öğretmene de öğrencilerin ilgileri, tavırları, intiyaçları, kullandıkları stratejiler ve başarı durumları hakkında bilgi verir. Okuma alanındaki değerlendirmeler ağırlıklı olarak teşhis edici mahiyettedir. Standart testlerin yanında, açık uçlu sorular, mülâkatlar, görüşmeler yoluyla da bilgi toplanabilir. Okuma öncesi yapılan ölçme ve değerlendirme çalışmaları ön bilgileri ve bu bilgilerin zenginlik düzeyini ortaya koymaya dönüktür. Ön bilgilerin etkili bir şekilde kullanılıp kullanılmadığı konusunda okuma öncesi yapılan ölçme ve değerlendirme çalışmaları da okuma sürecine katkı sağlayıcıdır (Akyol, 2007: 45). Dinleme becerilerinde de dinleme öncesi, sırası ve sonrasında ölçme ve değerlendirme kullanılabilir. Hatta dinleme öncesi ve sırasında ölçme ve değerlendirmeye yer verilmesi öğrencilerin daha aktif bir dinleme süreci geçirmesini sağlar.

Uyanık zihin, yalnız okuduğunu anlamakla kalmaz, değerlendirmeye ve ondan yararlanmaya da çalışır. Anlam, şu yönlerden değerlendirilir: a) Kapsamı, sınırı; b) Verilen bilgilerin güvenilirliği; c) Bilgi ve düşüncelerin gerçeklere uygunluğu; ç) Bu konuda başka yazarların düşünceleriyle karşılaştırma; eksiklerini, yeni yönlerini belirleme; d) Yazıda yaymaca amacı bulunup bulunmadığını bulma; e) Düşünceden çıkacak sonuçları kestirmeye çalışma; f) Okuyucunun, yazıdan öğrendikleriyle, eksik bilgisini tamamlaması, yanlış kanılarını düzeltmesi. Zihin bu değerlendirmeleri okuma sırasında az çok kendiliğinden yapar. Okuyucu, değerlendirdikten sonra edindiği bilgi ve kanıdan, kendi sorunlarını çözümlemekte yararlanır; davranışlarında bunlara uyar (Göğüş, 1978: 73).

Anlamayı ve onun değerlendirmesini daha iyi anlamak için, okuduğunu anlamayı ölçmenin tek bir en iyi yolu olmadığı ancak hem uyarıcının (metin) seçiminin hem de uyarıcının sunumunun (örneğin genel düzen ve görsel desteklerin kullanımı) ve cevap verme biçiminin (örneğin sabit tercih, açık cevap), okuduğunu anlama değerlendirmelerinde öğrenci performansını etkileyen boyutları bulunmaktadır. Aynı zamanda, okuduğunu anlama gözlemlenebilir sınav performansının kalıpları temelinde anlaşılabilen ancak doğrudan gözlemlenemeyen bir yetidir (Francis, Fletcher, Catts, Tomblin, 2005).

Dinleme ise sese dayalı bir beceri olduğu için dil alanları içerisindeki en soyut beceridir. Bu durum dinlemeyi güçleştiren, eksik ve yanlış dinlemeye yönelten bir faktördür. Dinlemenin soyut bir sürecinin olması, dinlemenin ölçülemez bir beceri olduğu yönünde yanlış yargılara neden olmakta ya da ölçme değerlendirme çalışmaları, dinleme becerisinin gelişiminin ölçülmesinden ziyade dinlenen metnin anlaşılıp anlaşıımadığının ölçülmesiyle sonuçlanmaktadır (Melanlıoğlu, 2012: 1586). 
Buck (2001: 1)’a göre dinlediğini anlama çok karmaşık bir süreçtir ve ölçümünde ilk önce sürecin nasıl işlediğini anlamak gerekir. Neyin ölçülmeye çalışıldığının anlaşııması, soruların yapılandırılmasında ilk adımdır. Ölçülmeye çalışılan şeye yapı adı verilir ve sorular sadece doğru yapıyı ölçerlerse faydalı ve geçerli olur. Bu yüzden, soruları hazırlayan kişinin yapması gereken ilk iş yapıyı anlamak ve daha sonra bu yapıyı bir biçimde ölçecek soruları oluşturmaktır.

Anlama becerisine yönelik araç hazırlarken veya seçerken en çok dikkat edilmesi gereken unsur metinlerdir. Ölçülmek istenilen amaca, öğrenci seviyesine uygun metin bulmak zor ve önemli bir süreçtir. Dinleme metinleri öğrencinin de önünde olmadığı için seçilecek metinlerin uzunluğu, kısalığı, öğrenci dikkatinin dağılma süresi gibi pek çok unsur dinlediğini anlamada etkili olmaktadır.

Dinlediğini ölçmek için muhtemelen en yaygın bir biçimde kullanılan etkinlikler dinlediğini anlama sorularıdır. Bunun ardında yatan fikir oldukça basittir: Bir metin öğrenciye sunulur ve daha sonra bağlamı ne kadar iyi anladığını ölçmek için hazırlanmış sorular sorulur. Anlama soruları çeşitli metin türleri ile çok çeşitli bilgi, beceri ve yetiyi ölçmek için kullanılabilir. Üstelik bunları oluşturması kolay gibi gözükmektedir (Buck, 2001: 134). Anlama becerilerinin ölçümünde hemen hemen her metinde metin altı anlama sorularından yararlanılır.

Ayrıca Mackay (1997: 24)'e göre dinleme soruları, ilgi gösterme veya destekleme biçiminde, daha fazla bilgi edinmeye, duyguları keşfetmeye, anlaşılanı göstermeye ya da söyleneni aydınlatmaya yönelik olabilir.

Ölçme ve değerlendirme ölçülmek istenilen amaca, alana göre farklı ölçme araçlarıyla yapılabilir. Ölçme araçları; sözlü ve yazılı sınavlar, kısa cevaplı, doğru-yanlış, çoktan seçmeli, eşleştirmeli, boşluk doldurmalı testler, gözlem ve görüşme formları, ölçekler, dereceli puanlama anahtarları, kontrol listeleri, öz, akran ve grup değerlendirmelerinden oluşur (Güler, 2011; Baykul, 2010; Özçelik, 2010a, 2010b; Karip, 2008; Hogan, 2007; Erkuş, 2006; Atılgan, Kan ve Doğan, 2006; Popham, 2005; Taylor ve Nolen, 2005; Linn ve Miller, 2005; Payne, 2003; Black, Harrison, Lee, Marshall ve William, 2003; Tekin, 1996).

Dil becerileri eğitiminde Program'da belirlenen hedeflere ulaşılıp ulaşıımadığını veya ne derecede ulaşıldığını saptamak için öncelikle söz konusu becerilerin iyi betimlenmesi, amaca uygun bir biçimde ölçütlerin belirlenmesi, bu ölçütlere göre puanlama anahtarının geliştirilmesi; tüm bunların yanı sıra ölçme aracının, ölçülecek beceri veya davranışları tam olarak ölçebilecek nitelikte seçilmesi beklenmektedir. Anlama becerilerinin ölçme ve değerlendirmesinde pek çok ölçme aracı kullanılabilir.

Anlama becerilerinin ölçme ve değerlendirmesindeki asıl amaç sistemli bir şekilde ilerlemenin sağlanması için amaca uygun ölçme ve değerlendirme araçlarının belirlenip uygulanması ve mutlaka öğrenciye durumu hakkında dönüt verilmesidir. 
Türkçe Öğretmenlerinin Anlama Becerilerinde Ölçme ve Değerlendirmeye Yönelik Görüşleri

Okuduğunu anlamanın değerlendirilmesi için çoklu metot yaklaşımlarının farklı değerlendirmelerin boyutlarını ele alan araştırmalar ve metotlardaki varyasyonların ilişkilerini değerlendiren araştırmalar ile birlikte kullanılması gerekir (Francis, Fletcher, Catts, Tomblin, 2005). Tek bir soru türü yerine anlama becerilerinde ölçülmek istenilen kazanıma veya özelliğe göre ölçme araçlarının çeşitlendirilmesi daha geçerli, daha kapsamlı bir ölçme yapılmasını sağlar.

Türkçe eğitimine yönelik ölçme ve değerlendirme çalışmalarının genel olarak 2005’e kadar çok gelişmediği görülmektedir. 2005'ten sonra ise hem doktora (Göçer, 2005) hem yüksek lisans tezi (Adıyaman, 2005; Zorbaz, 2005; Çakmak Akata, 2009; Beyhan 2012; Yiğit 2013) hem de makale (Göçer, 2007a, 2007b, 2007c, 2008a) düzeyinde çalışmalar kendini göstermektedir.

Türkçe eğitiminde ölçme ve değerlendirme kavramlarını doğrudan içeren çalışmalarda (Çakmak Akata, 2009; Yıldııım ve Karakoç Öztürk, 2009; Metin ve Demiryürek, 2009; Karadüz, 2009; Maden ve Durukan, 2011a; Kilmen ve Beyhan, 2011; Beyhan, 2012; Acar, 2012; Benzer ve Eldem, 2013; Yiğit, 2013; Arslan, 2013b; Yiğit ve Kırımlı, 2014) araştırmacıların Türkçe eğitiminin ölçme ve değerlendirme boyutunu Türkçe öğretmenlerinin gözünden, onların bilgisinden istifade ederek değerlendirmeye çalıştıkları görülmektedir.

Okuma becerisiyle ilgili çalışmalarda ise doğrudan ölçme ve değerlendirme başlığı taşıyan bir araştırmaya ulaşılamamıştır. Ancak Ertürk (2008)'ün veri toplama aracı olarak kullandığı yirmi sorudan ikisini, Karakoç Öztürk (2008)'ün ise altı boyuttan oluşan veri toplama aracının bir boyutunu okuma becerisinin ölçme ve değerlendirmesine ayırdığı görülmektedir.

Dinleme becerisine yönelik ölçme ve değerlendirme araştırmaları da sınırlı sayıdadır. Göçer (2008b) araştırmasında Türkçe dersi öğrenme ve öğretme süreci etkinlikleri arasında öğrencilere verilen performans görevlerinin dinleme becerilerine katkısı üzerinde durmuştur. Tabak ve Göçer (2014) dinleme becerisinde kullanılabilecek alternatif ölçme ve değerlendirme araçlarını tanıtmış ve örnekler vermiştir. Melanlıoğlu ve Karakuş Tayşi (2013) ise İlköğretim Türkçe Dersi (6, 7, 8. Sınıflar) Öğretim Programı ve Kılavuzu'nda dinleme/izleme öğrenme alanına yönelik ifade edilen kazanımları ölçme yöntem ve tekniklerine göre tasnif ederek dinleme/izlemede sürecin mi sonucun mu veya her ikisinin birden mi değerlendirmeye tabi tutulduğunu tespit etmişlerdir. Melanlıoğlu (2012) da araştırmasında Illköğretim Türkçe Dersi $(6,7,8$. Sınıflar) Öğretim Programı ve Kılavuzu ile alanyazındaki ölçme ve değerlendirme yöntemleri ve üstbiliş stratejilerini dinleme becerisi bakımından incelemiştir.

Alanyazında doğrudan anlama becerilerinin ölçme ve değerlendirmesine yönelik bir çalışma tespit edilmemiştir. Bu bilgiye YÖK Tez Veri Tabanı ve ULAKBIM UVT/Sosyal Bilimler Veri Tabanında “Türkçe Eğitimi, Türkçe Öğretimi, Türkçe Programı, kazanım, anlama, dinleme, izleme, okuma, ölçme, değerlendirme, ölçme aracı" anahtar kelimeleriyle yapılan tarama sonucunda ulaşılmıştır. 
Bu doğrultuda araştırmanın amacı, Türkçe öğretmenlerinin anlama becerilerinde ölçme ve değerlendirmeye yönelik görüşlerini tespit etmektir. Bu amaca yönelik cevaplar bulmak için aşağıdaki alt problemlerden yararlanılmıştır:

1. Türkçe öğretmenlerinin Türkçe eğitiminin ölçme ve değerlendirmesi hakkındaki görüşleri nelerdir?

2. Türkçe öğretmenlerinin okuma becerisinin ölçme ve değerlendirmesi hakkındaki görüşleri nelerdir?

3. Türkçe öğretmenlerinin dinleme/izleme becerisinin ölçme ve değerlendirmesi hakkındaki görüşleri nelerdir?

\section{Yöntem}

\section{Araştırmanın Modeli}

Bu araştırma, Türkçe öğretmenlerinin Türkçe eğitiminin, okuma becerisinin, dinleme/izleme becerisinin ölçme ve değerlendirmesine ilişkin görüşlerini incelemeye yönelik nitel bir çalışmadır.

Nitel araştırma, gözlem, görüşme ve doküman analizi gibi nitel bilgi toplama yöntemlerinin kullanıldığı, algıların ve olayların doğal ortamda gerçekçi ve bütüncül bir biçimde ortaya konmasına yönelik nitel bir sürecin izlendiği araştırmadır (Yıldırım, 1999: 10).

Nitel araştırmanın veri toplama yöntemleri görüşme, gözlem ve dokümanlardır. Nitel yöntemler içinde kullanımı en yaygın olan ise görüşme yöntemidir. Görüşme, temel veri toplama araçlarındandır. İnsanların gerçekliğe ilişkin algılarına, anlamlarına, tanımlamalarına ve gerçeği inşa edişlerine vâkıf olmanın bir yoludur. Aynı zamanda, başkalarını anlamak için kullanılan en güçlü yöntemlerdendir (Punch, 2005: 165-166). Bu doğrultuda Türkçe eğitiminin ölçme ve değerlendirmesi, okuma becerisinin ölçme ve değerlendirmesi, dinleme becerisinin ölçme ve değerlendirmesi boyutlarını Türkçe öğretmenlerinin bakış açısından keşfetmek amacıyla nitel araştırma yöntemlerinden görüşme yöntemi tercih edilmiştir.

\section{Çalışma Grubu}

Araştırmanın çalışma grubunu Türkçe öğretmenleri oluşturmaktadır. Çalışma grubundaki katılımcı sayısının belirlenmesinde araştırmada görüşme yönteminin tercih edilmesi etkili olmuştur. Çünkü Yıldırım ve Şimşek (2011)'in de belirttiği gibi çalışma grubuna dâhil edilecek birey ya da bireylerden elde edilmesi planlanan verinin derinliği ve genişliği çalışma grubunun büyüklüğü ile ters orantılıdır. Yani araştırmaya katılanlardan toplanacak verinin miktarı arttıkça çalışma grubuna dâhil edilmesi gereken bireylerin sayısı azalmaktadır. Alanyazın taramasında araştırma konusuyla ilişkili olan ve görüşme yöntemi kullanılan çalışmalarda 25-40 katılımcının olduğu belirlenmiştir. Bu doğrultuda 
araştırmanın amacına en iyi hizmet edeceği düşünülen amaçlı örnekleme yöntemlerinden maksimum çeşitlilik örnekleme yöntemi de göz önünde tutularak ön uygulamada 5, ana uygulamada ise 50 Türkçe öğretmeniyle görüşülmesine karar verilmiştir. Araştırmada da maksimum çeşitleme örnekleme yöntemi seçilerek çalışma grubunda maksimum farklılıklar elde edebilmek için a) cinsiyet, b) mezun olunan lisans türü, c) eğitim düzeyi, d) görev süresi, e) görev yapılan şehirler gibi demografik özelliklerin çeşitlilik göstermesine dikkat edilmiştir.

31 kişinin mezun olduğu lisans türü Türkçe Öğretmenliği, 12 kişinin Türk Dili ve Edebiyatı, 7 kişinin ise Sınıf Öğretmenliğidir. Öğretmenlerden 44'ünün eğitim durumu lisans, 5'inin yüksek lisans, 1'inin ise doktoradır. Görev süreleri ise 1-19 yıl arasında değişmektedir.

3'ünün görev süresi bir yıl, 8' inin görev süresi iki yıl, $1^{\prime}$ inin görev süresi üç yıl, $5^{\prime}$ inin görev süresi dört yıl, 2'sinin görev süresi beş yıl, 3'ünün görev süresi altı yıl, 1'inin görev süresi sekiz yıl, 3'ünün görev süresi dokuz yıl, 3'ünün görev süresi on yıl, 3'ünün görev süresi on iki yıl, 5'inin görev süresi on üç yıl, 4'ünün görev süresi on dört yıl, 4'ünün görev süresi on beş yıl, 1'inin görev süresi on altı yıl, 2'sinin görev süresi on yedi yıl, 1'inin görev süresi on sekiz yıl, 1'inin görev süresi on dokuz yıldır.

Türkçe öğretmenlerinin görev yaptığı şehirler ise Adana, Adıyaman, Afyon, Ağrı, Aksaray, Ankara, Antalya, Batman, Bitlis, Diyarbakır, Gaziantep, Gümüşhane, Hakkâri, İstanbul, İzmir, Kars, Kastamonu, Konya, Kütahya, Mardin, Mersin, Muğla, Muş, Niğde, Ordu, Sakarya, Samsun, Sivas, Şırnak, Urfa, Uşak, Yozgat'tır.

\section{Veri Toplama Aracı}

Araştırmanın amacı doğrultusunda alanyazın taranmış ve uygun veri toplama aracının hangisi olacağına karar verilmiştir. Derinlemesine bilgiler elde edebilmek amacıyla yarı yapılandırılmış görüşme yöntemi tercih edilmiştir.

Araştırmanın amacıyla ilgili açık uçlu sorulardan oluşan bir havuz oluşturulmuştur. Alan uzmanlarına liste sunulmuş ve önerileri doğrultusunda listeden araştırma için en çok önem arz edeceği düşünülen yirmi altı soru belirlenip düzenlenmiştir. Uzman görüşü için tablo oluşturulurken üçlü dereceleme ölçeği kullanılmış, "gerekli", "düzeltilmeli", "gereksiz" maddelerine yer verilmiştir. Hazırlıklar sonrasında soruların kapsam geçerliliğini sağlamak için Gazi Üniversitesi, Düzce Üniversitesi, Hacettepe Üniversitesi, Abant İzzet Baysal Üniversitesi, Mustafa Kemal Üniversitesi, Niğde Üniversitesi, Kırıkkale Üniversitesinde Türkçe Eğitimi alanında çalışan yedi öğretim üyesinin görüşleri alınmıştır. Uzmanlardan yaklaşık üç hafta gibi bir süreçte dönüt alınmıştır. Miles ve Huberman'ın uyum yüzdesi için önerdiği; Görüş birliği / toplam görüş birliği + görüş ayrılığı sayısı (Miles, Huberman, 2015: 64) formülü kullanılmıştır. 
Uzmanlardan gelen dönütlere göre $1,3,5,6,10,11,16,20,21$, 26. soruların uyum yüzdesi 0,$83 ; 7,9,17,19$. soruların uyum yüzdesi $0.91 ; 2,4,8,12,13,14,15,18,22,23,24,25$. soruların uyum yüzdesi ise 1 olarak bulunmuştur.

Daha sonra ön uygulama için beş Türkçe öğretmeniyle görüşme yapılmıştır. Görüşmenin haricinde katılımcılardan görüşme soruları ve süreciyle ilgili de dönüt vermeleri istenmiştir. Bu hâliyle yirmi üç soruluk Türkçe eğitiminin, okuma becerisinin, dinleme/izleme becerisinin ölçme ve değerlendirmesi boyutlarından oluşan bir yarı yapılandırılmış görüşsme formu elde edilmiştir. Ancak bu makalede kaldırılan TEOG sınavına ilişkin soruya (1.3) ve kazanımlar 2018'de değiştiği için okuma (2.9) ve dinleme (3.9) kazanımlarının ölçme ve değerlendirmesine ilişkin sorulara yer verilmemiştir, 20 görüşme sorusuna ilişkin bulgular yer almaktadır. Ayrıca öğretmenlerin cinsiyetine, mezun olunan lisans türüne, eğitim durumuna, eğitim düzeyine, görev süresine, görev yapılan şehirlere ilişkin demografik bilgilere de yer verilmiştir.

Sorulardan on ikisi deneyim ve davranış soruları olup şimdiki zamanda; on tanesi düşünce ve değer soruları olup sekizi şimdiki zamanda ikisi ise gelecek zamanda; bir soru ise şimdiki zamanda sorulmuş bilgi sorusudur.

\section{Verilerin Toplanması}

Görüşme için okullara gidilmiş, araştırmanın amacı hakkında Türkçe öğretmenlerine bilgi verilmiş ve gönüllü olan Türkçe öğretmenleriyle boş bir sınıf bulunarak görüşülmüştür. Okul ortamında görüşülmeyen Türkçe öğretmenleriyle de randevu saati ayarlanmış ve sessiz bir ortamda görüşme yapılmıştır.

Görüşme öncesinde Türkçe öğretmenlerinden izin alınarak görüşme verilerini kayıt etmede en güçlü yöntem olan ses kayıt cihazıyla kayıt yapılması istenmiştir. Kırk bir öğretmen ses kayıt cihazının kullanılmasına izin vermiştir. Ancak dokuz Türkçe öğretmeni ses kayıt cihazının kullanılmasını istemedikleri için görüşme sırasında ve sonrasında not alınmıştır. Bu şekilde görüşme verilerinin tamamına yakınının korunması sağlanmıştır.

Görüşmeler bizzat araştırmacı tarafından yapılmıştır. Görüşmeler en az 30 dakika, en fazla 90 dakika, ağırlıklı olarak ise 50-70 dakika aralığında sürmüştür. Ses kayıtları, Times New Roman yazı tipinde 12 punto yazı tipi boyutunda yazıya geçirilerek 234 sayfalık ham veri elde edilmiştir.

\section{Verilerin Analizi}

Araştırmada nitel verilerin analiz yöntemlerinden içerik analizi yöntemi kullanılmıştır.

Nitel veri analizinin güçlülüklerini en aza indirgemek için araştırmada nitel veri analiz sürecine adım adım uyulmuştur. Merriam (2013), Yıldıım ve Şimşek (2011), Marshall ve Rossman (2006)'ın 
belirttikleri nitel veri analizi süreçleri incelenmiş ve ortak bir veri analiz süreci görüşme verilerinin çözümlemesinde kullanılmıştır.

- Verilerin kodlanması: Araştırmada toplanan bütün görüşme kayıtları yazıya geçirildikten sonra öğretmenlere Ö1, Ö2, Ö3... şeklinde kodlar verilmiştir. Öğretmen görüşleri soru sırasına göre tek tek incelenmiştir. Ayrıca bir soruya ait bütün cevaplar ayrı bir klasörde de toplanarak cevapların bütününün görülmesi ve ihtiyaç hâlinde kolaylıkla kontrol edilebilmesi sağlanmıştır. Okumalar yapılırken her anlamlı bölümün kavramsal olarak ne ifade etmeye çalıştığı düşünülmüştür. Araştırmanın analiz birimi cümlelerdir. Cümleler özgün şekli bozulmadan alınmaya çalışılmıştır. Görüşme verileri okunurken kâğıtların sağ tarafına bu anlamlı bölümleri özetleyen kodlar yazılmıştır. Kodlama sayesinde anlam bakımından benzer olan görüşlerin bir araya getirilmesi ve ilişkilendirilmesi mümkün olmuştur.

- Temaların bulunması: Sorulara ilişkin bütün görüşler ve kodlar hazırlandıktan sonra kodlara tekrar dönülerek kodlar gruplandırılmaya çalışılmıştır. Kodlar bir araya getirilip incelenmiş ve ortak yönler bulunmaya çalışılmıştır. Araştırma soruları temaların ortaya çıkarılmasında yol gösterici olmuştur.

- Verilerin kodlara ve temalara göre düzenlenmesi: Ortaya çıkan kodlar ve temalar düzenlenmiş, frekans dağılımları eklenmiş, bu aşamada görüş ve yorumlara yer verilmeden bilgiler işlenerek okuyucuya bulgular bölümünde sunulmuştur.

- Bulguların yorumlanması (Raporlaştırma): Bu aşamada toplanan verilere anlam kazandırmak için bulgular arasındaki ilişkiler açıklanmış neden-sonuç ilişkileri kurulmuş bulgulardan birtakım sonuçlar çıkarılmış elde edilen sonuçlara ilişkin açıklamalarda bulunulmuş ve diğer araştırmalarla karşılaştırılmıştır. Bu aşama sonuç ve tartışma bölümünde raporlaştırılmıştır. Araştırma sonuçları ortaya konduktan sonra diğer araştırmalarla karşılaştırılarak doğrulanmıştır. Görüşme verilerinin güvenirliğini sağlamak için iki yöntem kullanılmıştır.

Türnüklü’nün (2000, s. 551), Croll (1986), Robson (1993: 222), Bakeman ve Gottman (1997: 60)'dan aktardığına göre görüşme tekniğine yönelik bir güvenirlik yöntemi kayıtların tutarlılı̆̆ına bakılmasıdır. Görüşmeden sonra elde edilen kayıtların çözümlemesinde ortaya çıkabilecek yanlışların azaltılması için bu süreçte de çözümleme tutarlılığına bakılması gerekmektedir. Bunun için uyuşum yüzdesi formülü “P = Na x 100 / Na x Nd” (P: Uyuşum yüzdesi, Na: Uyuşum miktarı, Nd: Uyuşmazlık miktarı) kullanılabilir. Bu doğrultuda ilk kodlamadan dört hafta sonra rastgele seçilen 15 öğretmenin görüşmelerinden elde edilen kayıtlar araştırmacı tarafından tekrar incelenmiş, iki çözümlemedeki kodlamalar karşılaştırılarak uyuşum yüzdesi formülüne göre hesaplanmış ve uyuşum yüzdesi 0,97 bulunmuştur. 
Kullanılan diğer güvenirlik yöntemi de üç ayrı uzman tarafından kodlama yapılmasıdır. Araştırmacı tarafından güvenirlik için kullanılmayan 35 öğretmenden rastgele şekilde seçilen 15 öğretmenin kayıtları başka iki uzman tarafından incelenmiştir. Daha sonra kodlamalar karşılaştırılarak kodlama benzerlikleri ve farklılıkları hesaplanmıştır. Uyuşum yüzdesi formülü "Güvenirlik = Görüş birliği sayısı / toplam görüş birliği + görüş ayrılığı sayısı" (Miles ve Huberman, 2015: 64) kullanılarak araştırmacı ve uzmanlar arasındaki uyuşum yüzdesi 0,93 bulunmuştur. Sonrasında ise farklııklar tartışlarak en aza indirgenmiştir.

\section{Bulgular}

Bu bölümde Türkçe Eğitiminin, okuma ve dinleme becerilerinin ölçme ve değerlendirmesine ilişkin bulgulara yer verilmiştir.

\section{Türkçe Eğitiminin Ölçme ve Değerlendirmesi}

Türkçe öğretmenlerine "Ölçme ve değerlendirme kavramları hakkında bilgi verir misiniz?" sorusu yöneltilmiştir. Bazıları ölçme ve değerlendirme kavramlarını ayrı ayrı, bazıları tek bir kavrammış gibi tanımlamışlar, bazıları da ölçme ve değerlendirmenin iş̧levinden bahsetmişlerdir. Buradan hareketle temalar "ölçme", "değerlendirme”, "ölçme ve değerlendirme", "ölçme ve değerlendirmenin işlevi" şeklinde dörde ayrılmıştır. Ölçme temasına ilişkin toplam yedi kodlama ortaya çıkmıştır. Öğretmen görüşlerine göre en fazla ifade edilen kodlama "Öğrenciye verilenin ne kadar kazandırıldığını tespit etme"dir. Bu kodlamanın frekansı 9'dur. Öğretmenlerden 4'ü ölçmeyi kazanımlara indirgemiş "Kazanımların öğrencide ne derecede var olduğunu tespit etme" olarak tanımlamışlardır. Diğer sık kullanılan kodlama da "Öğrenciye verilenin ne kadarını alıp almadığının rakamla veya sembolle ifade edilmesi" şeklindedir. 4 öğretmenin ölçme tanımlarından bu kodlama oluşturulmuştur. 22 öğretmen ölçme kavramını tek başına tanımlamıştır ve hepsinin doğru kabul edilebilir tanımlamalar yaptığı görülmektedir. Bu durumda 50 öğretmenden 22'sinin ölçme kavramını tanımlayabildiği 28'inin ise tanımlayamadığı söylenebilir. Değerlendirme temasına ilişkin toplam 12 kodlama ortaya çıkmıştır. En fazla tekrar eden ilk kodlama "Öğrencinin geçmesi, kalması, derste başarılı olması, istenen düzeye ulaşamaması" şeklindedir. Diğer sık kullanılan kodlama "ìi kötü yeterli yetersiz gibi bir değer verme" şeklindedir. Yapılan tanımlardan ortaya çıkan 12 kodlamanın ilk 10 tanesinin doğru, 11 ve 12.'nin ise yanlış olduğu görülmektedir. 30 öğretmen ölçme ve değerlendirme kavramlarını tek bir kavrammış gibi tanımlamışlardır. Bu doğrultuda ölçme ve değerlendirme temasına ilişkin 16 kod ortaya çıkmıştır. 9 öğretmenin tanımlarıyla ilk sırada gelen kodlama "Öğrencinin verilenin ne kadarını aldığını tespit etme"dir. 5 öğretmenin ölçme ve değerlendirmeyi kazanım düzeyine indirgeyerek tanım yaptığı görülmektedir. İlk 11 kodlamanın ya ölçmenin tanımı ya da değerlendirmenin tanımı olduğu görülmektedir. Son 5 kodlama $(12,13,14,15,16)$ ise yanlıştır. 9 öğretmen ise ölçme ve değerlendirmenin tanımını değil ne işe yaradığını belirtmişler ve 7 kodlama ortaya çıkmıştır. 3 
öğretmenin ağırlıklı olarak belirttiği kodlama “Öğretmene öğrenciyi ve kendisini değerlendirme, eksikleri giderme fırsatı sunar." şeklindedir.

Türkçe öğretmenlerine "Türkçe eğitiminde ölçme ve değerlendirmeyi nerelerde (hangi amaçlarla) kullanıyorsunuz?" sorusu yöneltilmiştir. Öğretmenler genellikle öğretim sürecinin hangi aşamasında ve hangi amaçla ölçme ve değerlendirmeyi kullandıklarını belirtmişlerdir. Verilen cevaplara göre şu şekilde 4 tema ortaya çıkmıştır: Sürecin başında, süreçte, sürecin sonunda ve süreci belirtilmeyen. Ayrıca bu cevapların dışında öğretmenler bahsettikleri süreçte veya amaç için ne tür bir uygulama yaptıklarını da dile getirmişlerdir. 13 öğretmenin öğretim sürecinin başında ölçme ve değerlendirmeyi kullandıkları görülmektedir. 7 kodlama ortaya çıkmıştır. 4 öğretmen sürecin başında öğrencilerin hazırbulunuşluk seviyesini ölçmek için ölçme ve değerlendirmeyi kullandığını belirtmiştir. Diğer çok değinilen kodlama "Öğrencilerin ön bilgilerinin tespiti" 4 öğretmenin verdiği cevaplarla oluşmuştur. Öğretmenler ayrıca amaçlarını gerçekleştirmek için neler yaptıklarından da bahsetmişlerdir. Çoktan seçmeli testler yapma, e-okuldan önceki sınav notlarına bakma, sınav yapma, sesli okuma yaptırma, belgeselleri ve kısa filmleri kullanma, soru sorma öğretmenlerin sürecin başında amaçlarına ulaşmak için yaptıkları uygulamalardır. Süreçte temasına ilişkin 13 kodlama ortaya çıkmıştır. 26 öğretmen öğretim sürecinin içinde ölçme ve değerlendirmeyi kullandıklarını belirtmişlerdir. Bu öğretmenlerin yarısı (13 kişi) ise amaçlarının "Konunun anlaşılıp anlaşılmadığını kontrol etme" olduğunu ifade etmişlerdir. Ayrıca öğretmenler kendilerinden istenmediği hâlde aralarda yaptıkları ölçümlere yönelik olarak nasıl bir uygulama gerçekleştirdiklerini de belirtmişlerdir. 8 öğretmen tema değerlendirme sorularını yaptırdığını, 6 öğretmen de soru sorduğunu belirtmiştir. Bunların dışında yapılanlar da şu şekildedir: Tekrar ettirme; çalışma kâğıtları kullanma; test ve sözlü yapma; okuma, konuşma, yazma ölçekleri kullanma; il ve ilçe bazındaki değerlendirmeleri kullanma; gözlem yapma; kılavuz kitaptaki bütün etkinlikleri yaptırma; ders içi performans değerlendirme; çeşitli ölçme araçları oluşturma ya da kriterler belirleme; proje görevlerini değerlendirme. Sürecin sonunda temasına ilişkin 8 kodlama ortaya çıkmıştır. 32 öğretmenin öğretim sürecinin sonunda ölçme ve değerlendirmeyi kullandıkları görülmektedir. Ağırıklı olarak 23 kişi "not verme" amacıyla kullanmaktadır. Bu durumu ders içi gözlemi sözlü notuna yansıtma, yazılı, sözlü, test yapma gibi yöntemlerle gerçekleştirmektedirler. Öğretim sürecinin hangi aşamasında kullandığını belirtmeden sadece ne amaçla kullandığını belirten öğretmenler olmuştur. Bu şekilde 7 kodlama, 17 öğretmen görüşü bulunmaktadır. 8 öğretmenin amacı "Dil alanlarını ölçme"dir. Türkçe eğitiminde ölçme ve değerlendirmenin kullanımına ilişkin bulgularda 10 öğretmenin sürecin başında, 26 öğretmenin süreçte, 32 öğretmenin sürecin sonunda ölçme ve değerlendirmeyi kullandıkları görülmektedir. Öğretmenlerin çok azı sürecin başında ölçme ve değerlendirmeyi kullanmaktadır. Süreçte ölçme ve 
değerlendirme yapan öğretmenlerin çoğunun amacı konunun anlaşlıp anlaşılmadığını kontrol etmektir. Sürecin sonunda ölçme ve değerlendirme yapanların amacı ise not vermedir.

Türkçe öğretmenlerine "Türkçe Dersi Öğretim Programı ve kitaplarda pek çok ölçme ve değerlendirme aracı sunulmaktadır. Bu araçlarla ilgili görüşleriniz nelerdir?" sorusu sorulmuştur. Öğretmenler pek çok aracı kullandıklarını veya kullanmadıklarını, bazıları kullanma veya kullanmama sebeplerini de belirtmişlerdir. Öğretmen görüşlerine göre 17 tema ortaya çıkmıştır. Temalar şu şekildedir: Çoktan seçmeli sorular, doğru-yanlış soruları, eşleştirme soruları, kısa cevaplı sorular, açık uçlu sorular, performans ödevi, öğrenci ürün dosyası, proje ödevi, öz değerlendirme, akran değerlendirme, etkinlik, ölçme araçları, gözlem, dereceli puanlama anahtarı, tutum ölçeği, tema değerlendirme soruları, ders içi performans. Çoktan seçmeli soruları 11 öğretmen kullandığını, 1 öğretmen ise kullanmadığını belirtmiştir. Çoktan seçmeli soruları kullanan öğretmenlerin gerekçeleri zaman açısından iyi olması, kapsamının geniş olması, öğrencinin zorlanmaması, net ölçüm sağlaması, alt düzey bilgileri ölçmesi gibi sebeplerdir. Doğru-yanlışsorularını 6 öğretmen zaman açısından iyi ve kapsamı geniş olduğu için kullandığını, 1 öğretmen ise Türkçenin yapısına uymadığı için kullanmadığını belirtmiştir. Eşleştirme sorularını 6 öğretmen öğrencilerin derse motive olmaları, öğrencilerin kolay yapması, sevmesi ve alt düzey bilgileri ölçmesi sebepleriyle kullandıklarını belirtmişlerdir. Eşleştirme sorularını kullanmadığını belirten öğretmen olmamıştır. 9 öğretmen kısa cevaplı soruları kullandıklarını belirtmişlerdir. Kullanma nedenleri ise öğrencinin derse motive olması, zaman açısından iyi olması, kapsamının geniş olması, öğrencinin sevmesi ve alt düzey bilgileri ölçmesidir. Kısa cevaplı soruları kullanmadığını belirten öğretmen ise olmamıştır. 14 öğretmen açık uçlu soruları kullandıklarını belirtmişlerdir. Kullanma sebepleri ise öğrencilerin düşüncelerini ifade etmesi, öğrencilerin derste konuşmayı sevmeleri, öğrencinin ilerlemesi, diğer soru türlerinin öğrenciye bir şey katmaması, öğrencinin okuduğunun anlaşılması, öğrencinin sürekli test olması, öğrencinin daha aktif olmasıdır. Açık uçlu soruları kullanmadığını belirten öğretmen bulunmamaktadır. Performans ödevinin kullanımıyla ilgili görüş belirtilmezken 10 öğretmen performans görevlerini kullanmadığını ifade etmiştir. Kullanmama sebepleri öğrencilerin kütüphane, internet imkânının olmaması; ödevi ailesinin yapması; öğretmenin değerlendirmesinin zor olması, öğretmenin evinde ödev için yer bulamaması; değerlendirme için ölçeğin olmaması; çok sağlıklı olmaması; amacına yönelik olmaması; angarya olarak algılanması; öğrencinin internetten yapması; öğrencinin araştırma durumunun olmaması; faydalı olmaması; ağaçların kurtulması; öğrenci için yük olmasıdır. 1 öğretmen, öğrenci ürün dosyasını öğrenci hakkında not tutup velisiyle paylaşmak için kullandığını belirtirken 4 öğretmen, öğrenci ürün dosyasını kullanmadıklarını belirtmiştir. Öğretmenler kullanmama nedenleri olarak Programın, okulların alt yapısının uygun olmamasını; gereksiz olmasını; ayrıntının fazla olmasını; öğrencinin kâğıtlar içerisinde kaybolmasına gerek olmamasını, verimli olmamasını, öğrencilerin ürünlerini sene sonuna kadar 
Türkçe Öğretmenlerinin Anlama Becerilerinde Ölçme ve Değerlendirmeye Yönelik Görüşleri

muhafaza etmemelerini göstermektedir. Proje ödevini 2 öğretmen kullandığını 2 öğretmen ise kullanmadığını belirtmiştir. Öğretmenlerin kullanma nedenleri, öğrenciden el yazısıyla ödevini hazırlamasını istemesi ve diğer öğrencilerin soru sorması; kullanmama nedenleri ise öğrencinin süreçte öğretmenle birlikte çalışmaması, yaratıı bir şeylerin ortaya konmaması, fotokopi veya çıktı getirilmesi, ailenin etkisinin olması ve ödevin gerçeği yansıtmamasıdır. 3 öğretmen öz değerlendirmeyi; konuşma becerisi için güzel olması ve öğrencilerin alışması için kullandığını belirtirken 4 öğretmen ise çok sağlıklı olmaması, kültürel, ahlaki olarak uygun olmaması, öğrencinin bilinçli ve objektif olmaması, öğretmen ve öğrenci açısından gereksiz olması, öğretmenin zaten öğrenciyi bilmesi gibi sebeplerle kullanmadığını belirtmektedir. Akran değerlendirmeyi; konuşma becerisi için güzel olması ve öğrencilerin alışması için kullandığını belirten 3 öğretmen, çok sağlıklı olmaması, kültürel, ahlaki olarak uygun olmaması, öğrencinin bilinçli olmaması, uygulanabilirliğinin olmaması, öğrencilerin objektif olamaması, öğretmen ve öğrenci açısından gereksiz olması, öğretmenin zaten öğrenciyi bilmesi gibi sebeplerle kullanmadığını belirten 6 öğretmen görüşü bulunmaktadır. Öğretmenlerden $5^{\prime} \mathrm{i}$, etkinlikleri kullandığını dil bilgisi etkinliklerinin güzel olduğunu, öğrenilenlerin pekiştirilmesini sağladığını, öğrencilerin bulmaca tarzı etkinlikleri sevdiğini belirtmişlerdir. 9 öğretmen ise bazılarının uzun olması, birbirinin tekrarı niteliğinde olması, öğrencinin sıkılması, işleniş sırasının aynı olması, beşinci sınıflarda çok fazla etkinlik olması, seviyeye uygun olmaması, sekizinci sınıf için basit olması, sürenin yetmemesi, öğrencinin etkinlikleri anlamaması, çalışılan okula, bölgeye uymaması, yazma etkinliklerinin çok üst düzey olması gibi nedenlerle kullanmadıklarını belirtmişlerdir. Öğretmenlerin bazıları hangi ölçme araçlarını kullandığını belirtmeden genel olarak ölçme araçları hakkındaki görüşlerini söylemişlerdir. 8 öğretmen ölçme ve değerlendirme araçlarını kullandığını, 15 öğretmen ise kullanmadığını belirtmiştir. 4 öğretmen sonuç alabildiklerini kullandığını, ekleme yapması gerektiğini, her öğrencinin seviyesine uygun olanları kullandığını, çok zor araç olmadığını, kılavuzdaki araçları kullandığını, sınav kâğıdı üzerinde kullanılabilecekleri kullandığını, öğrencinin zevkle doldurduğunu ve öğrencinin not kaygısından uzaklaştığını belirtmişlerdir. 15 öğretmenin ise kullanmama nedenleri şunlardır: Her çocuk için uygulanabilir olmaması, orta düzey öğrencilerin hazırbulunuşlukları düşünülerek hazırlanması, taksonominin alt basamaklarında sorular olması, birbirini tekrar etmesi, sınıf mevcudunun fazla olması, zamanın az olması, öğretmenin ek araçlar geliştirmesi, öğrenciye yaptırabilmenin zor olması, ölçmenin öğrenci için zor olması, konuların yoğun olması, amacına uygun sonuçlar vermemesi, çok ayrıntılı olması, tek tek uygulamanın zor olması, öğrenciyle paylaşmayınca etkisinin olmaması, öğrencilerin çok alt seviyede olması, Türkiye'deki bütün okullar için uygun olmaması, öğretmenin nasıl kullanacağını bilmemesi, ne işe yarayacağının bilinmemesi, hazırlayanların okul deneyimi olmaması, başka eğitim sistemlerinden uyarlanmış olması, öğretmenin zaten öğrencinin durumunu bilmesi, kâğıt israfı olması, öğrencilerin aynı cevapları vermesidir. Gözlemi iki öğretmen kullandıklarını belirtmişlerdir. Görüşme yöntemine dair hiçbir öğretmen görüş bildirmemiştir. 1 öğretmen dereceli puanlama anahtarını 
kullanmadığını belirtmiştir. 1 öğretmen tutum ölçeklerini sağlıklı bulmadığı için kullanmadığını belirtmiştir. Tema değerlendirme sorularını 3 öğretmen kullandığını 1 öğretmen ise kullanmadığını belirtmiştir. Ders içi performansı 4 öğretmen "Yıl boyunca yapılan gözlemlerin sonucu"nda kullandığını 1 öğretmen ise gerçeği yansıtmadığı ve öğrenci puanını etkilememek için kullanmadığını belirtmiştir. Ayrıca öğretmenler görüşlerini ifade ederken şu önerilerde bulunmuşlardır: Kitaplarda ölçme ve değerlendirme kısımları daha eğlenceli olmalı, farklı şablonlarla öğrencinin zihinsel olarak geliştirilmesine katkı sağlanmalı, 5. sınıflarda dil bilgisi konularına ilişkin ölçme ve değerlendirme fazlalaştırılmalı, uzun cevap gerektiren sorular sorulmalı, öğretmen elindeki malzemeye göre kriter belirlemeli soru hazırlamalı, ölçme araçları seviyelendirilmeli, her temanın sonunda değerlendirme formu olmamalı, ölçme ve değerlendirme araçları çeşitli olmalı, ölçülecek kazanımın niteliğine göre araç belirlenmeli, öğrencinin ön planda olduğu araçlar kullanılmalı, Program güncellenmeli, etkinlikler zenginleştirilmeli, dönütlere göre baskılarda düzeltme yapılmalı. Öğretmenlerin ağırlıklı olarak çoktan seçmeli soruları, açık uçlu ve kısa cevaplı soruları kullandıkları görülmektedir. Öğretmenler performans ödevi, öğrenci ürün dosyası, proje ödevi, öz değerlendirme, akran değerlendirme, etkinlikleri ve genel olarak ölçme ve değerlendirme araçlarını kullanmadıklarını belirtmişlerdir. Gözlem, dereceli puanlama anahtarı ve tutum ölçekleri, tema değerlendirme soruları, ders içi performansa yönelik çok az öğretmen görüş bildirirken görüşme ve grup değerlendirme yöntemlerine ilişkin hiçbir öğretmen görüş belirtmemiştir.

Türkçe öğretmenlerine "Okuma, dinleme/izleme, konuşma, yazma, dil bilgisi alanlarına göre ayrı ayrı puanlama yapıp ortalama alıyor musunuz?" sorusu yöneltilmiştir. Bu doğrultuda "puanlama yapmama" ve "puanlama yapma" temaları olmak üzere iki tema ortaya çıkmıştır. Toplam 41 öğretmen dil alanlarına göre ayrı ayrı puanlama yapmadıklarını belirtmişlerdir. 23 kodlama ortaya çıkmıştır. Değerlendirmelerini ağırlıklı olarak "Ders içi performans değerlendirme" (9 öğretmen) ve "Yazılı sınavda okuma, yazma, dil bilgisi sorarak değerlendirme" (16 öğretmen) şeklinde yaptıklarını ifade etmişlerdir. Puanlama yapma temasında puanlama yapma nedenine ilişkin 2 kodlama, puanlamanın nasıl yapıldığına ilişkin 10 kodlama ortaya çıkmıştır. 9 öğretmen dil alanlarına göre ayrı ayrı puanlama yaptıklarını belirtmişlerdir. Nedenleri ise Türkçe Öğretim Programı'nda yapılmasının istenmesi; dinleme ve konuşmanın farklı ölçme araçlarıyla değerlendirilmesi gereğidir. Öğretmenler uygulamada da ağırlıklı olarak yazııı sınavda okuma, yazma, dil bilgisi sorarak değerlendirme; ders içi etkinliklerde ise dinleme ve konuşma becerilerini puanlayarak değerlendirme yapmaktadır. Öğretmenlerin büyük çoğunluğu dil alanlarına göre ayrı ayrı puanlama yapmamaktadır. Puanlama yapanlar da yazılı sınav ve ders içi performansla puanlama yapmaktadır. Şekil 1'de "Türkçe eğitiminin ölçme ve değerlendirmesi" boyutuna ilişkin temalar gösterilmiştir. 

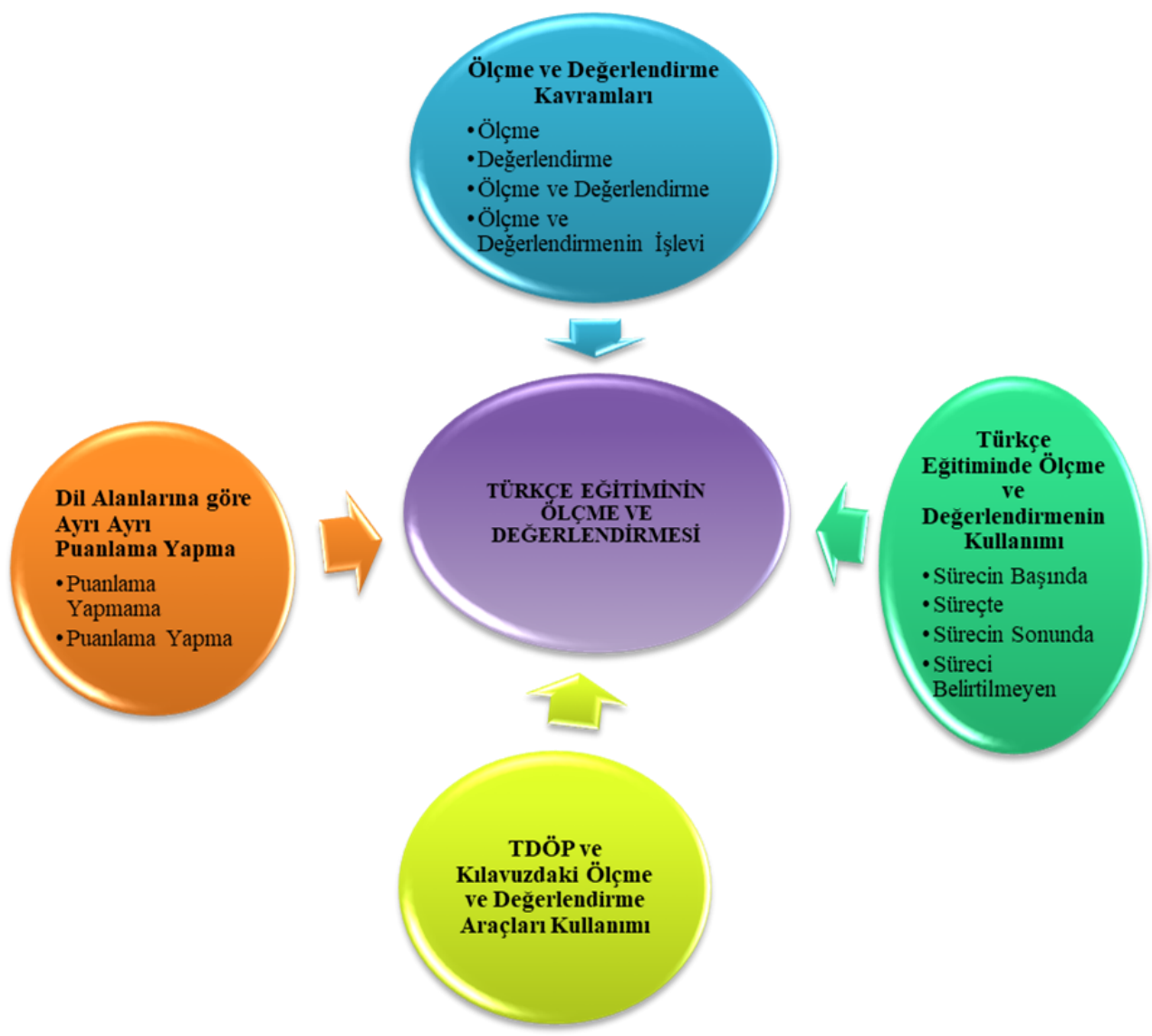

Şekil 1. Türkçe eğitiminin ölçme ve değerlendirmesi

\section{Okuma Becerisinin Ölçme ve Değerlendirmesi}

Türkçe öğretmenlerine "Okuma becerisine yönelik ölçme aracı hazırlıyor musunuz?" sorusu yöneltilmiştir. 31 öğretmen okuma becerisine yönelik ölçme aracı hazırladığııı, 19 öğretmen ise hazırlamadığını belirtmiştir. Bu soru doğrultusunda "Evet" cevabını verenler neler yaptıklarını, "Hayır" cevabını verenler neden yapmadıklarını ifade etmişlerdir. Hazırlamaya ilişkin 9 kodlama, hazırlamamaya ilişkin 5 kodlama ortaya çıkmıştır. 31 öğretmen okuma becerisine yönelik ölçme aracı hazırladığını belirtmiştir. Öğretmenlerin yazılılarda, okuma parçası ve anlama soruları; test veya doğrudan metinden bulmaya ve yorumlamaya dayalı sorular, hikâye veya roman paragrafına yönelik ana fikir, olay, yer, zaman soruları, metinle ilgili kısa cevaplı, açık uçlu, eşleştirme, boşluk doldurma, test soruları hazırladıkları görülmektedir. Yazılı dışında da öğretmenlerin öğrencinin seviyesine göre konu bulup soru oluşturdukları, kazanımlara göre okuduğunu değerlendirme ölçeği hazırladıkları, zümre olarak kitaplara yönelik açık uçlu sorular hazırladıkları, öğrencinin okuduğu hikâye kitaplarına göre soru hazırladıkları, okuma metnine yönelik kısa cevaplı, açık uçlu, eşleştirmeli, boşluk doldurma soruları hazırladıkları görülmektedir. 19 öğretmen okuma becerisine yönelik ölçme aracı hazırlamadığını ifade etmiştir. Ölçme aracı hazırlamamalarının nedeni olarak ise öğrencinin süreçte değerlendirilmesi, kritere gerek olmaması, kritere dikkat edilince bir şeylerin kaçırılabilmesi, gözlemin 
yeterli olması, ölçme araçlarının kılavuz kitaplarda olmasını göstermişlerdir. Öğretmenlerin çoğunun okuma becerisine yönelik ölçme aracı hazırladığı ortaya çıkmıştır.

Okuma becerisine yönelik ölçme aracı hazırladığını belirten 31 Türkçe öğretmenine "Okuma becerisine yönelik ölçme aracı hazırlarken nelere dikkat edersiniz?" sorusu yöneltilmiştir. Öğretmenlerin dikkat ettiği noktalar metin seçme ve ölçme aracı temaları etrafında toplanmıştır. Metin seçmeye yönelik 21 öğretmen görüşü, 14 kodlama ortaya çıkmıştır. Öğretmenler metin seçme konusunda en fazla sınıfın düzeyine uygun olmasına (5 öğretmen) ve öğrencinin ilgisini çekmesine (3 öğretmen görüşü) dikkat etmektedir. Ölçme aracı temasına ilişkin 29 öğretmen görüşü, 17 kodlama ortaya çıkmıştır. Ölçme aracı temasında da en fazla (11 öğretmen) dikkat edilen nokta "metin seçme" temasında olduğu gibi "Sınıfın düzeyine uygun olması"dır. Öğretmenlerin metin seçme ve ölçme aracı hazırlamada ağırlıklı olarak dikkat ettikleri nokta sınıfın düzeyine uygun olmasıdır.

Türkçe öğretmenlerine "Okuma becerisinin ölçümünde kullandığınız ölçme araçları nelerdir?” sorusu yöneltilmiştir. Bu doğrultuda şu şekilde 13 kodlama ortaya çıkmıştır: Çoktan seçmeli sorular, doğru-yanlış soruları, eşleştirme soruları, kısa cevaplı sorular, açık uçlu sorular, öz değerlendirme, akran değerlendirme, gözlem, kitaptaki etkinlikler, okuma kitabı, okuma hızı, takipli anlatım, öğrencinin soru hazırlaması. 7 öğretmen çoktan seçmeli soruları, 3 öğretmen doğru-yanlışsorularını kullandığını belirtmiş ancak kullanma sebebini dile getirmemiştir. 3 öğretmen eşleştirme sorularını metnin anahtar noktalarının kavranıp kavranmadığını belirleme, zıt ve eş anlamlı kelimeler için kullandıklarını belirtmişlerdir. 11 öğretmen kısa cevaplı soruları kullandığını belirtmiştir. Kullanma sebepleri ise şunlardır: Metnin konusunu, ana fikrini buldurma, hikâye unsurlarını belirletme, bilgi düzeyinde soru sorma, net bilgi içermesi, öğrencinin ne kadar anladığını belirleme. 26 öğretmen okuma becerisi için açık uçlu soruları kullandıklarını ifade etmiştir. Ölçme araçları içinde en fazla kullanılanı açık uçlu sorulardır. Açık uçlu sorular; öğrencinin düşüncesini geliştirmeye yönelik şeyleri tercih etme, öğrencinin yorumlayabilmesi, karakterin yerine kendini koyma, ana fikri buldurma, öğrencinin düşüncesini ifade edebilmesi, öğrencinin anladığını yazması, öğrencinin ne kadar anladığını belirleme amaçlarıyla kullanılmaktadır. Akran değerlendirme 3 öğretmen tarafından etkili olduğu ve öğrencilerin birbirleriyle olan durumlarını gözlemleme, sesli okumayı ölçme amaçlarıyla yapılmaktadır. 4 öğretmen kitaptaki etkinlikleri yaptırdığını ifade etmiştir. 9 öğretmen öğrencilerin Türkçe dersi sürecinde ve dışında okudukları kitaplara (okuma kitabı) yönelik kitap tanıtım fişi, kitap okuma formu, kitabı özetleme, kitapla ilgili soru sorma ve sordurma yöntemlerini kullanmaktadır. 3 öğretmen öğrencinin okuma hızını ölçmektedir. 1 öğretmen ise adına takipli anlatım dediği bir yöntemi kullandığını belirtmiştir. Bu yöntemde okuduğunu anlama, anlatılanı dinleme, devam ettirebilme söz konusudur. Yine 1 öğretmen de öğrencilere soru hazırlattığını belirtmiştir. Öğretmenlerin okuma becerisine yönelik performans görevi, öğrenci ürün dosyası, proje ödevi, grup değerlendirme, görüşmeyi kullanmadıkları; 
en fazla açık uçlu, kısa cevaplı, çoktan seçmeli soruları kullandığı; okuma kitabına yönelik etkinlikler yaptırdıkları görülmektedir.

Türkçe öğretmenlerine "Öğretmen kılavuz kitabı ve çalışma kitabındaki okuma becerisine yönelik ölçme ve değerlendirme uygulamaları hakkında ne düşünüyorsunuz?" sorusu yöneltilmiştir. Bu soruya ilişkin ortaya çıkan 4 tema şu şekildedir: Ölçme araçları, metin, nitelik, uygulama. Kılavuz kitabındaki ölçme araçlarına yönelik olumlu ve olumsuz yönde öğretmen görüşleri bulunmaktadır. Olumsuz öğretmen görüşlerine ilişkin 19 kodlama, 24 öğretmen görüşü; olumlu öğretmen görüşlerine ilişkin 8 kodlama, 14 öğretmen görüşü yer almaktadır. Ölçme araçlarına yönelik öğretmen görüşlerinin ağırlıklı olarak olumsuz olduğu görülmektedir. Olumlu görüşler olumsuzlar kadar fazla değildir. Metinlere ilişkin 7 kodlama, 16 öğretmen görüşü bulunmaktadır. Metinlere yönelik görüşlerin tamamı olumsuzdur. Ağılıkı olarak öğretmenler, metnin; öğrenci seviyesine hitap etmemesi (5 öğretmen görüşü) ve uzun olmasından (4 öğretmen görüşü) şikâyet etmektedir. Nitelik temasına ilişkin olumsuz yönde 5 kodlama, 14 öğretmen görüşü; olumlu yönde 3 kodlama, 7 öğretmen görüşü yer almaktadır. Öğretmenlerin ölçme ve değerlendirme uygulamalarının niteliğine ilişkin olarak 4 öğretmen yayınevine göre değişmesini ve 7 öğretmen yetersiz olmasını olumsuz bulmaktadırlar. Öğretmenlerin okuma becerisinin ölçme ve değerlendirme uygulamalarına yönelik olumlu ve olumsuz görüşleri vardır. Olumsuz yönde 13 kodlama 23 öğretmen görüşü, olumlu yönde 3 kodlama 4 öğretmen görüşü bulunmaktadır. 6 öğretmen okuma becerisine yönelik ölçme ve değerlendirme uygulamalarının hepsini uygulayamadıklarını, seçim yaptıklarını veya atlayarak kullandıklarını belirtmişlerdir. Okuma becerisine yönelik ölçme ve değerlendirme uygulamalarını olumlu bulan öğretmenler uygun olanları kullandıklarını, ilave yapmak zorunda kalmadıklarını, her tema sonunda değerlendirme yaptıklarını belirtmişlerdir. Öğretmenler okuma becerisinin ölçme ve değerlendirme uygulamalarına ilişkin şu önerilerde bulunmuşlardır: Bu alanda çalışma yapan hocaların yaptığı etkinliklerin dikkate alınması, olaya dayalı metinlerin yer alması, bir kazanımın hep aynı etkinlik tarzıyla ölçülmemesi, ders saatinin fazlalaştırıması, aynı soru kalıbının kullanılmaması, soru çeşitlerinin farklılaştırılması. Öğretmen kılavuz kitabı ve çalışma kitabındaki okuma becerisine yönelik ölçme ve değerlendirme uygulamalarına ilişkin öğretmenler; ölçme araçları, metinler, nitelik, uygulama açısından genellikle olumsuz görüş belirtmişlerdir.

Türkçe öğretmenlerine "Okuma kazanımlarıyla birebir eşleştirilmiş ölçme araçları hakkındaki görüşünüz nedir?” sorusu yöneltilmiştir. Öğretmenlerin bir kısmı okuma kazanımlarıyla birebir eşleştirilmiş ölçme araçları hakkında olumlu görüş bildirirken ağırlıklı bir kısmı da olumsuz görüş bildirmiştir. Olumlu yönde 7 kodlama, 19 öğretmen görüşü; olumsuz yönde 14 kodlama, 33 öğretmen görüşü bulunmaktadır. Okuma kazanımlarıyla birebir eşleştirilmiş ölçme araçları hakkında olumlu görüş bildiren öğretmenlerden 9'u "yeterli" olduğunu belirtmektedir. Diğer olumlu bulunan yön de 
“öğretmeni yönlendirmesi”dir. Öğretmenlerin 5’i bu yönde görüş bildirmiştir. Okuma kazanımlarıyla birebir eşleştirilmiş ölçme araçları hakkında olumsuz görüş bildiren öğretmenler olumlu görüş bildirenlerden daha fazladır. 11 öğretmen okuma kazanımlarıyla birebir eşleştirilmiş ölçme araçlarını uygulamadığını belirtmiştir. Uygulamama nedeni olarak zamanlarının olmamasını, öğrencinin objektif değerlendirme yapamamasını, uygulama kriterlerinin olmamasını, öğretmene kimsenin dönüt vermemesini öne sürmektedir. 7 öğretmen de okuma kazanımlarılla birebir eşleştirilmiş ölçme araçlarının hepsini uygulamadığını dile getirmiştir. Neden olarak da zaman olmamasını, hepsini yaptırmanın gereksiz olmasını, bir araçla pek çok kazanımın ölçülebilmesini ve yararlı olanları seçtiklerini belirtmişlerdir. Okuma kazanımlarıyla birebir eşleştirilmiş ölçme araçlarını öğretmenlerin bir kısmı yeterli olduğu ve öğretmeni yönlendirdiği için olumlu bulurken, büyük bir kısmı ise uygulamadıklarını ya da hepsini uygulamadıklarını belirterek olumsuz yönde görüş bildirmişlerdir.

Türkçe öğretmenlerine "Sizce bir öğretmen okuma becerisinin ölçme ve değerlendirmesi açısından hangi yeterliklere (bilgi ve becerilere) sahip olmalıdır?" sorusu yöneltilmiştir. Öğretmenlerin görüşleri temalara ayrıştırılırken "MEB öğretmen yeterlikleri” esas alınmıştır. Bu doğrultuda 6 tema ortaya çıkmıştır: Kişisel ve meslekî değerler-meslekî gelişim; öğrenciyi tanıma; öğretme ve öğrenme süreci; öğrenmeyi, gelişimi izleme ve değerlendirme; okul, aile ve toplum ilişkileri; program ve içerik bilgisi. Öğretmenlerin bazılarının görüşleri doğrudan ölçme ve değerlendirmeyle ilgili değildir. Ancak öğretmen yeterliklerine girdiği ve öğretmenler dolaylı da olsa ölçme ve değerlendirmeyle ilişkilendirdikleri için temalarda yer verilmiştir. Ancak araştırma doğrultusunda önem arz eden tema "Öğrenmeyi, gelişimi izleme ve değerlendirme” temasıdır. Kişisel ve meslekî, değerler-meslekî gelişim temasına ilişkin 7 kodlama, 23 öğretmen görüşü yer almaktadır. Kişisel ve meslekî, değerler - meslekî gelişim temasında ağırlıklı olarak 14 öğretmen, bir öğretmenin öncelikle iyi bir okuyucu olması gerektiğini vurgulamıştır. Öğrenciyi tanıma temasına yönelik 6 kodlama, 12 öğretmen görüşü bulunmaktadır. Öğrenciyi tanıma temasına ilişkin kodlamalarda en fazla "öğrencinin yaşına, ilgisine hitap eden kitapları önermeli" görüşleri yer almaktadır. Diğer sık ifade edilen görüş de "Öğrencinin seviyesine uygun metinler seçmeli" kodlamasıdır. Okuma becerisinin öğrenme ve öğretme sürecine ilişkin 12 kodlama, 19 öğretmen görüşü bulunmaktadır. Görüşler ağırlıklı olarak “örnek okuma yapmalı” (3 öğretmen) ve "bir metni veya kitabı okumayı öğretmeli" (3 öğretmen) şeklindedir. Öğrenmeyi, gelişimi izleme ve değerlendirme temasına ilişkin 18 kodlama, 29 öğretmen görüşü bulunmaktadır. Öğretmen görüşlerinin en fazla "Öğrencilere okuduğunu anlamaya yönelik değerlendirme soruları sormalı" (5 öğretmen) kodlamasında toplandığı görülmektedir. 4 öğretmen "Okuma düzeyini tespit etmek için öğrenciyi gözlemlemeli" kodlamasına yönelik görüş belirtmiştir. 3 öğretmenin görüşleri ise "Öğrencinin okuduğunu anlayıp anlamadığını değerlendirmeli” kodlamasını oluşturmaktır. Okul, aile ve toplum ilişkileri temasına yönelik 3 öğretmen görüş belirtmiştir. Görüşlerden ortaya çıkan kodlamalar 
"velinin desteğini almalı" ve "öğrenci ve aileyle işbirliği içinde olmalı" şeklindedir. Program ve içerik bilgisi temasına ait 9 kodlama, 13 öğretmen görüşü bulunmaktadır. Bunlardan ikisi "Ölçme ve değerlendirme tekniklerini bilmeli" ve "Okuma becerisini nasıl ölçeceğini bilmeli" kodlamaları doğrudan ölçme ve değerlendirmeyle ilgilidir. Öğretmenler okuma becerisinin ölçme ve değerlendirmesinde ağırlıklı olarak bir öğretmenin iyi bir okuyucu olması; öğrencinin yaşına, ilgisine hitap eden kitapları önermesi, öğrencilere okuduğunu anlamaya yönelik değerlendirme soruları sorması gerektiğini vurgulamışlardır.

Türkçe öğretmenlerine "Okuma becerisinin ölçümünde karşılaştığınız sorunlar nelerdir?" sorusu yöneltilmiştir. Öğretmenlerin belirttikleri görüşler MEB’le, öğretmenle, öğrenciyle, aileyle ilgili sorunlar olmak üzere 4 temada toplanmıştır. MEB ile ilgili sorunlar temasına ilişkin 5 kodlama, 14 öğretmen görüşü yer almaktadır. Öğretmenler MEB'le ilgili sorunlar temasında en fazla (8 öğretmen) sınıfların kalabalık olmasından şikâyet etmektedirler. Öğretmen ile ilgili sorunlar temasına ilişkin 15 kodlama, 24 öğretmen görüşü bulunmaktadır. 5 öğretmen okuma becerisinin ölçümüne ilişkin sorun olarak zamanın yetmemesini göstermektedir. 3 öğretmeninin görüş bildirdiği “öğrencilerin hepsinin okumasını kontrol etmeye imkân olmaması" kodlaması 5 öğretmenin görüş bildirdiği "zamanın yetmemesi" kodlamasını desteklemektedir. 3 kişinin görüş bildirdiği diğer bir kodlama da "okumayazma bilmeyen öğrencinin sınıfını geçmesi”dir. Öğrenci ile ilgili sorunlar temasına ilişkin 17 kodlama, 46 öğretmen görüşü bulunmaktadır. 7 öğretmen okuma becerisinin ölçümüne ilişkin sorun olarak öğrencilerin okuma güçlüğü olmasını görmektedir. Ayrıca 4 öğretmen de bu durumdaki öğrenciye diğer öğrencilerin müdahale etmesinin öğrenciyi olumsuz yönde etkilediğini belirtmişlerdir. 7 öğretmen öğrencilerin "okuma alışkanlıklarının olmaması"nı sorun olarak ifade etmişlerdir. Öğretmenlerin dile getirdiği diğer bir sorun "öğrencinin dikkatini dağıtan şeyler yüzünden okumayı sevmemesi"dir. 6 öğretmenin belirttiği diğer bir sorun da öğrencilerin "okuduğunu anlamaması"dır. Aile ile ilgili sorunlar temasına ilişkin 7 kodlama, 7 öğretmen görüşü bulunmaktadır. Aslında kodlamalar birbirine benzerdir. Yapılacak olan ailenin okuma için üzerine düşeni yapması ve çocuğuyla birlikte okumasıdır. Öğretmen görüşlerine göre okuma becerisinin ölçümünde karşılaşılan sorunlar ağılıklı olarak sınıfların kalabalık olması, zamanın yetmemesi, öğrencinin okuma güçlüğü olması, okuma alışkanlıklarının olmaması, öğrencinin dikkatini dağıtan şeyler yüzünden okumayı sevmemesi, okuduğunu anlamamasıdır.

Türkçe öğretmenlerine "Okuma becerisinin ölçme ve değerlendirmesinde değişiklik yapmak isteseniz neleri değiştirirsiniz?" sorusu yöneltilmiştir. Öğretmen görüşleri MEB'e, öğretmene ve aileye yönelik öneriler olmak üzere 3 temaya ayrılmıştır. MEB'e yönelik önerilerde 23 kodlama, 40 öğretmen görüşü bulunmaktadır. MEB'e yönelik iki önemli öneri "sınıf mevcutları azaltılmalı" (6 öğretmen) ve “metinler gözden geçirilmeli”dir (6 öğretmen). Metinlerin gözden geçirilmesi gerektiğini belirten 6 öğretmen metinlerin; kısa, öğrenci seviyesine uygun, merak uyandırıcı, gerçekçi, güncel, öğrenciye 
edebî zevk aşılayacak, çocuk edebiyatının yeni yazarlarından seçilmiş, bölgenin kültürel yapısına uygun olmasını istemektedir. Öğretmene yönelik öneriler temasında 14 kodlama, 19 öğretmen görüşü bulunmaktadır. Öğretmenlerin kendilerine yönelik belirttiği öneriler ağılıklı olarak (3 öğretmen) “öğrenciyle birebir ilgilenmeli”dir. Aileye yönelik öneriler temasında 4 kodlama, 4 öğretmen görüşü yer almaktadır. Okuma becerisinin ölçümünde öğretmenlerin aileye yönelik verdikleri öneriler; aileye öğrencinin takibi hakkında eğitim verilmesi, velinin işin içine katılmasının yasal dayanak hâline getirilmesi, veli ile işbirliği yapılması, evde ölçülebilecek şeyler hakkında velilerin değerlendirme yapıp öğretmene dönüt vermesidir. Okuma becerisinin ölçümüne yönelik önerilerde öğretmenler ağırıklı olarak sınıf mevcudunun azaltılması, metinlerin yeniden gözden geçirilmesi, öğrenciyle birebir ilgilenilmesi gerektiğini vurgulamışlardır. Şekil 2'de "Okuma becerisinin ölçme ve değerlendirmesi" boyutuna ilişkin temalar gösterilmiştir.

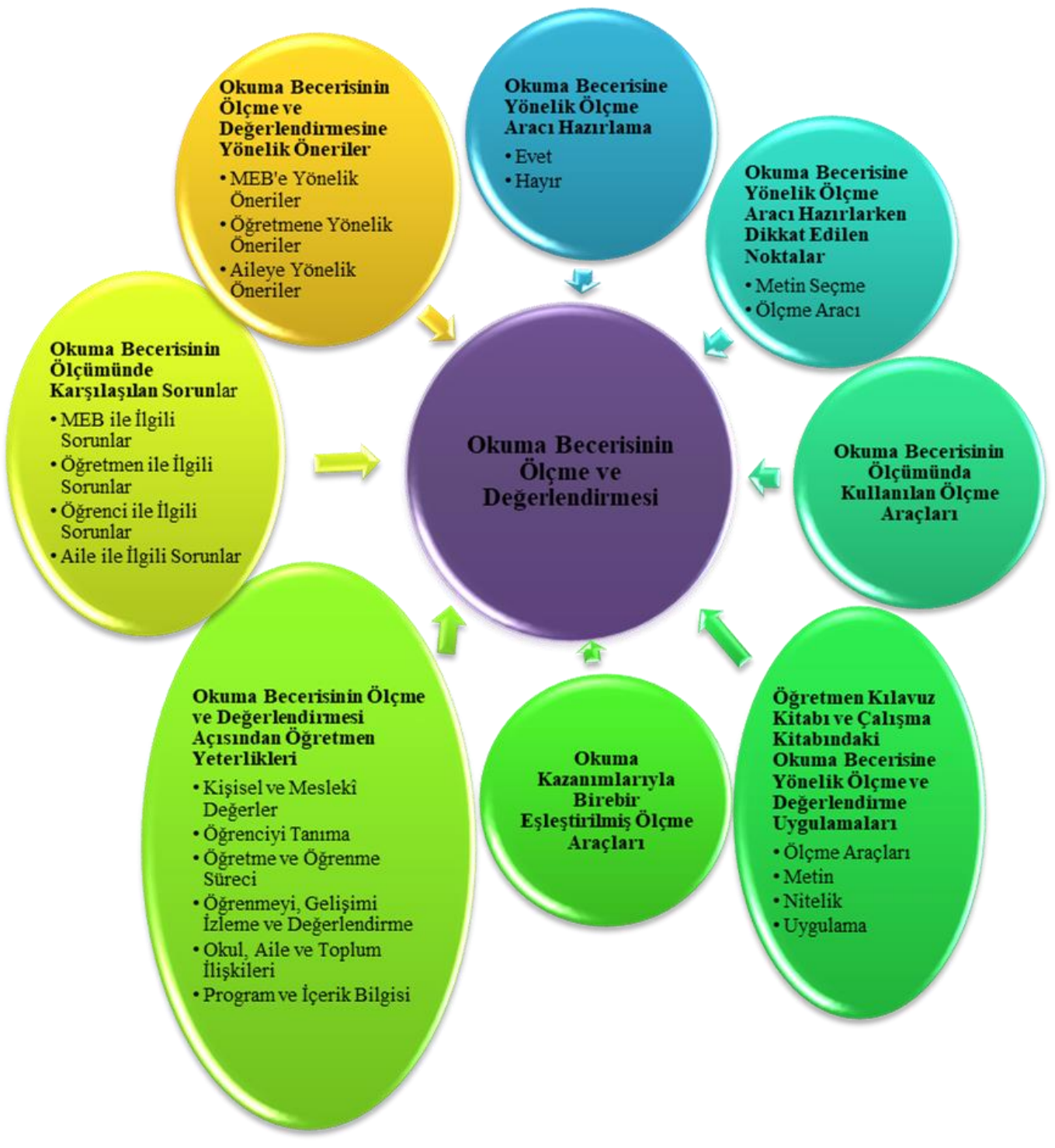

Şekil 2. Okuma becerisinin ölçme ve değerlendirmesi 
Türkçe Öğretmenlerinin Anlama Becerilerinde Ölçme ve Değerlendirmeye Yönelik Görüşleri

\section{Dinleme/izleme Becerisinin Ölçme ve Değerlendirmesi}

Türkçe öğretmenlerine "Dinleme/izleme becerisine yönelik ölçme aracı hazırlıyor musunuz?" sorusu yöneltilmiştir. Soruya 14 öğretmen "evet" cevabını vermiş ve görüşleri ile 5 kodlama, 36 öğretmen "hayır" cevabını vermiş ve görüşleri ile 2 kodlama ortaya çıkmıştır. Dinleme/izleme becerisine yönelik ölçme aracı hazırladığını belirten 14 öğretmenden 6'sı "dinleme metni bulma ve metne yönelik sorular sorma" şeklinde ölçme aracı hazırladığını belirtmektedir. Dinleme becerisine yönelik ölçme aracı hazırlamayan 36 öğretmen hazırlamama nedeni olarak öğretmen kılavuz kitabında olmasını (7 öğretmen) ve ders içinde anlık dönütlerle ölçtüklerini (2 öğretmen) ileri sürmektedir. Öğretmenlerin çoğunun dinleme/izleme becerisine yönelik ölçme aracı hazırlamadığı ortaya çıkmıştır.

Dinleme/izleme becerisine yönelik ölçme aracı hazırladığını belirten 14 Türkçe öğretmenine “Dinleme/izleme becerisine yönelik ölçme aracı hazırlarken nelere dikkat edersiniz?” sorusu yöneltilmiştir. Öğretmenlerin dikkat ettiği noktalar metin seçme ve ölçme aracı olmak üzere 2 tema etrafında toplanmıştır. Metin seçme temasına ilişkin 5 kodlama, 10 öğretmen görüşü bulunmaktadır. Metin seçme temasında öğretmenler ağılıklı olarak seçtikleri metnin "öğrencinin ilgisini çekmesi”ne (4 öğretmen) dikkat ettiklerini belirtmişlerdir. Ölçme aracı temasına ilişkin 11 kodlama, 16 öğretmen görüşü bulunmaktadır. Öğretmenlerin ölçme aracı hazırlarken en fazla dikkat ettikleri durum "metnin önemli noktalarından soru sorma"dır (4 öğretmen). Öğretmenlerin ağırlıklı olarak dinleme/izleme becerisine yönelik ölçme aracı hazırlarken seçtikleri metinlerin öğrencinin ilgisini çekmesine ve metnin önemli noktalarından soru sormaya dikkat ettikleri görülmektedir.

Türkçe öğretmenlerine "Dinleme/izleme becerisinin ölçümünde kullandığınız ölçme araçları nelerdir?" sorusu yöneltilmiştir. Bu doğrultuda şu şekilde 13 kodlama ortaya çıkmıştır: Doğru-yanlış soruları, eşleştirme soruları, kısa cevaplı sorular, açık uçlu sorular, öz değerlendirme, akran değerlendirme, gözlem, kılavuzdaki ölçekler, kitaptaki etkinlikler, öğrencinin soru hazırlaması, özetleme, anlattırma, tahmin etme. 3’er öğretmen doğru yanlış ve eşleştirme sorularını kullandığını belirtmiştir. 17 öğretmen kısa cevaplı soruları kullandığını belirtmiştir. Kullanma sebepleri ise bilgi düzeyinde sorular olması, metinde doğrudan cevabının olması ve metindeki önemli noktaların ölçülmek istenmesidir. 23 öğretmen dinleme/izleme becerisi için açık uçlu soruları kullandıklarını ifade etmiştir. Ölçme araçları içinde en fazla kullanılanı açık uçlu sorulardır. Açık uçlu sorular; metnin anlaşııp anlaşılmadığını belirleme, öğrencinin kendini ifade etmesi amaçlarıyla kullanılmaktadır. Öz ve akran değerlendirmeyi 2'şer, gözlemi 1, kılavuzdaki ölçekleri 2, kitaptaki etkinlikleri 4 öğretmen kullandığını belirtmiştir. 2 öğretmen ise öğrencilere soru hazırlattığını belirtmiştir. 6 öğretmen öğrencilerine dinlediklerini özetletmektedir. 4 öğretmen öğrencilerin dinlediklerini anlattırdıklarını belirtmişlerdir. 5 öğretmen dinleme/izlemede tahmin etme yöntemini kullandıklarını ve bunun çok etkili olduğunu ifade etmişlerdir. Öğretmenlerin dinleme/izleme becerisine yönelik çoktan seçmeli soruları, performans 
görevi, öğrenci ürün dosyası, proje ödevi, grup değerlendirme, görüşmeyi kullanmadıkları görülmektedir. Ayrıca öğretmenlerin en fazla açık uçlu, kısa cevaplı soruları kullandığı görülmektedir.

Türkçe öğretmenlerine "Öğretmen kılavuz kitabı ve çalışma kitabındaki dinleme/izleme becerisine yönelik ölçme ve değerlendirme uygulamaları hakkında ne düşünüyorsunuz?" sorusu yöneltilmiştir. Bu doğrultuda ölçme araçları, metin, nitelik, uygulama şeklinde 4 tema ortaya çıkmıştır. Ölçme araçları temasına ilişkin olumsuz 10 kodlama, 13 öğretmen görüşü; olumlu 7 kodlama, 8 öğretmen görüşü bulunmaktadır. Kılavuz kitap ve çalışma kitabındaki dinleme/izleme becerisine yönelik ölçme araçları hakkındaki olumsuz görüşler olumlu görüşlerden fazladır. Öğretmenler tarafından en fazla olumsuz görülen durumlar "ölçme araçlarının birbirini tekrar etmesi” (3 öğretmen) ve "bazılarının etkinlik sayısını artırmak için konulması"dır (2 öğretmen). Metin temasına yönelik olumsuz 11 kodlama, 30 öğretmen görüşü; olumlu 2 kodlama, 2 öğretmen görüşü bulunmaktadır. Metinlere yönelik görüşlerin ağırlıklı olarak olumsuz olduğu görülmektedir. 12 öğretmen metinlerin çok uzun olmasının öğrencilerin dikkatini toplayamamasına, soruları cevaplayamamasına ve dinlediği metni unutmasına sebep olduğunu belirtmektedir. Nitelik temasına ilişkin olumsuz 3 kodlama, 8 öğretmen görüşü; olumlu 2 kodlama, 7 öğretmen görüşü bulunmaktadır. Öğretmenlerin çoğunluğu dinleme/izleme becerisine yönelik ölçme ve değerlendirme uygulamalarını "yetersiz" (4 öğretmen) bulmakta ve "yayınevine göre değişmesi"nden (3 öğretmen) rahatsız olmaktadırlar. Öğretmenlerin olumlu buldukları yönler ise ağırlıklı olarak "yeterli" (6 öğretmen) olmasıdır. Dinleme/izleme becerisine yönelik ölçme ve değerlendirme uygulamalarını nitelik olarak bazı öğretmenlerin yeterli, bazılarının yetersiz bulduğu görülmektedir. Uygulama temasına yönelik olumsuz 7 kodlama, 21 öğretmen görüşü; olumlu 3 kodlama, 4 öğretmen görüşü bulunmaktadır. 8 öğretmenin dinleme/izleme becerisine yönelik ölçme ve değerlendirme uygulamalarını kullanmadıkları görülmektedir. Kullanmama nedeni olarak öğrencinin sıkılması, zamanın yetişmemesi, öğrenci seviyesine uygun olmamasını göstermektedirler. 7 öğretmen ise dinleme/izleme etkinliklerinin hepsini yaptırmadıklarını belirtmişlerdir. Müfredatın yetişmeyeceği endişesi, öğrencinin yorulması, öğrencinin derse hazır gelmemesi, sınıfların kalabalık oluşunu sebep olarak dile getirmektedirler. Öğretmenler, öğretmen kılavuz kitabı ve çalışma kitabındaki dinleme/izleme becerisine yönelik ölçme ve değerlendirme uygulamalarına ilişkin ölçme araçlarının birbirini tekrar etmesi, metinlerin çok uzun ve düşünce yazılarının olması, dinleme etkinliklerinin hepsini yaptırmama veya kullanmama şeklinde genellikle olumsuz yönde görüş bildirmişlerdir.

Türkçe öğretmenlerine "Dinleme/izleme kazanımlarıyla birebir eşleştirilmiş ölçme araçları hakkındaki görüşünüz nedir?" sorusu yöneltilmiştir. Öğretmenlerin bir kısmı dinleme/izleme kazanımlarıyla birebir eşleştirilmiş ölçme araçları hakkında olumlu görüş bildirirken bir kısmı da olumsuz görüş bildirmiştir. Olumlu yönde 5 kodlama, 11 öğretmen görüşü; olumsuz yönde ise 18 
Türkçe Öğretmenlerinin Anlama Becerilerinde Ölçme ve Değerlendirmeye Yönelik Görüşleri

kodlama, 29 öğretmen görüşü bulunmaktadır. Dinleme/izleme becerisine yönelik birebir eşleştirilmiş ölçme araçları için olumlu görüş bildiren öğretmenlerin 7'si "yeterli" bulduğunu belirtmektedir. 8 öğretmen dinleme/izleme becerisine yönelik ölçme araçlarını kullanmadığını belirtirken 4'ü de seçerek kullandığını belirtmektedir. Öğretmenlerin dinleme/izleme becerisindeki birebir eşleştirilmiş ölçme araçlarına ilişkin olumludan ziyade olumsuz görüş bildirdikleri görülmektedir.

Türkçe öğretmenlerine "Sizce bir öğretmen dinleme/izleme becerisinin ölçme ve değerlendirmesi açısından hangi yeterliklere (bilgi ve becerilere) sahip olmalıdır?" sorusu yöneltilmiştir. Öğretmenlerin görüşleri temalara ayrıştırılırken “MEB öğretmen yeterlikleri” esas alınmıştır. Bu doğrultuda 5 tema ortaya çıkmıştır: Kişisel ve meslekî değerler-meslekî gelişim; öğrenciyi tanıma; öğretme ve öğrenme süreci; öğrenmeyi, gelişimi izleme ve değerlendirme; program ve içerik bilgisi. Öğretmenler "okul, aile ve toplum ilişkileri" yeterliğine ait görüş bildirmemiştir. Öğretmenlerin bazılarının görüşleri doğrudan ölçme ve değerlendirmeyle ilgili değildir. Ancak öğretmen yeterliklerine girdiği ve öğretmenler dolaylı da olsa ölçme ve değerlendirmeyle ilişkilendirdikleri için temalarda yer verilmiştir. Ancak araştırma doğrultusunda önem arz eden tema "Öğrenmeyi, gelişimi izleme ve değerlendirme" temasıdır. Kişisel ve meslekî, değerler - meslekî gelişim temasında 9 kodlama, 26 öğretmen görüşü bulunmaktadır. Ağırlıklı olarak 14 öğretmen, bir öğretmenin öncelikle iyi bir dinleyici olması gerektiğini vurgulamıştır. 4 öğretmen de "iyi bir okuyucu olması" gerektiğini belirtmiştir. Öğrenciyi tanıma temasında 5 kodlama, 6 öğretmen görüşü bulunmaktadır. Kodlamalar her öğrenciye vakit ayırmalı, öğrenciyi tanımalı, öğrencinin anlayıp anlamadığını ölçerken rencide etmemeli, öğrencinin dinleme seviyesini bilmeli, öğrenciyi kırmadan eleştirmeli şeklindedir. Öğretme ve öğrenme süreci temasına ilişkin 11 kodlama, 25 öğretmen görüşü bulunmaktadır. Görüşler ağırlıklı olarak “öğrenciyi dinleme için güdüleyebilmeli” (6 öğretmen), "öğrenci seviyesine göre metinler seçmeli” (5 öğretmen) kodlamalarında toplanmıştır. Öğrenmeyi, gelişimi izleme ve değerlendirme temasına ilişkin 14 kodlama, 18 öğretmen görüşü bulunmaktadır. 3 öğretmen görüşünün “öğrencinin dinleyip dinlemediğini ölçmeli" kodlamasında toplandığı görülmektedir. 2 öğretmene göre "metinle ilgili sorular sormalı"dır. 2 öğretmene göre de bir öğretmenin "hazırladığı ölçme aracının maddeleri amaca hizmet etmeli"dir. Program ve içerik bilgisi temasına yönelik 2 kodlama, 3 öğretmen görüşü bulunmaktadır. Görüşler "alanına hâkim olmalı", "Program’a hâkim olmalı" şeklindedir. Öğretmenlere göre, dinleme/izleme becerisinin ölçme ve değerlendirmesi açısından bir öğretmen ağırlıklı olarak iyi bir dinleyici olmalı, öğrenciyi dinleme için güdüleyebilmeli, öğrenci seviyesine göre metinler seçmeli, öğrencinin dinleyip dinlemediğini ölçmelidir.

Türkçe öğretmenlerine "Dinleme/izleme becerisinin ölçümünde karşılaştığınız sorunlar nelerdir?" sorusu yöneltilmiştir. Öğretmenlerin belirttikleri görüşler MEB'le, öğretmenle, öğrenciyle, aileyle ilgili sorunlar olmak üzere 4 temada toplanmıştır. MEB'le ilgili sorunlara yönelik 10 kodlama, 18 
öğretmen görüşü bulunmaktadır. Öğretmenler dinleme/izleme becerisinin ölçümünde ağılıklı olarak sınıfın fizikî yapısı (4 öğretmen) ve öğrenci sayısının fazla olmasından (5 öğretmen) şikâyet etmektedirler. Öğretmen ile ilgili sorunlar temasına ilişkin 10 kodlama, 14 öğretmen görüşü bulunmaktadır. 3'er öğretmen dinleme becerisini ölçmenin zaman alması ve dinleme becerisini ölçemediklerinden yakınmaktadır. Öğrenci ile ilgili sorunlar temasına ilişkin 11 kodlama, 30 öğretmen görüşü bulunmaktadır. Dinleme/izleme becerisinin ölçümüne ilişkin 15 öğretmen öğrencinin “dikkatinin dağılması” yüzünden sorun yaşadıklarını belirtmişlerdir. Diğer önemli buldukları sorun ise “öğrencinin dinlememesi” dir (6 öğretmen). Aile ile ilgili sorunlar temasına yönelik ise 1 öğretmen görüş bildirmiştir. Öğretmenlerin dinleme/izleme becerisinin ölçümünde karşılaştıkları sorunlar ağırlıklı olarak öğrenci sayısının fazla olması, sınıfın fizikî yapısı, dinleme becerisini ölçmenin zaman alması, dinleme becerisini ölçememe, öğrencinin dikkatinin dağılması ve dinlememesidir.

Türkçe öğretmenlerine "Dinleme/izleme becerisinin ölçme ve değerlendirmesinde değişiklik yapmak isteseniz neleri değiştirirsiniz?" sorusu yöneltilmiştir. Öğretmen görüşleri MEB'e, öğretmene ve aileye yönelik öneriler olmak üzere 3 temaya ayrılmıştır. MEB'e yönelik önerilerde 16 kodlama, 46 öğretmen görüşü bulunmaktadır. 17 öğretmen dinleme metinlerinin değiştirilmesini istemektedir. Değiştirilmesi durumundaki istekleri ise şu şekildedir: Olay ağırlıklı metinler olmalı, öğrencinin ilgisini çekmeli, yabancı kaynaklı metinler olmamalı, kısa olmalı, mizahî yönü ağır olmalı, her metinde hem okuma hem dinleme yaptırımalı, bir okuma bir dinleme metni olmalı, şairlerin ya da yazarların sesinden metin seslendirilmeli. Diğer ağılıklı olan öğretmen görüşleri de "uygun bir dinleme ortamı sağlanmalı" (6 öğretmen), “öğrenci sayısı azalmalı” (5 öğretmen) şeklindedir. Öğretmene yönelik önerilerde 13 kodlama 15 öğretmen görüşü bulunmaktadır. 3 öğretmenin görüşü “metne yönelik sorular oluşturmalı" kodlamasını oluşturmaktadır. Aileye yönelik öneriler temasında 2 kodlama, 2 öğretmen görüşü bulunmaktadır. Bunlar, evde okuma yaptırılmalı, öğrenciye dinleme becerisinin kazandırıması için aileye eğitim verilmelidir. Öğretmenler, dinleme/izleme becerisinin ölçme ve değerlendirmesine yönelik ağırlıklı olarak metinler değişmeli, uygun bir dinleme ortamı sağlanmalı, öğrenci sayısı azalmalı, öğretmenlere teknolojik imkânlar sağlanmalı, metne yönelik sorular oluşturmalı şeklinde önerilerde bulunmuşlardır.

Şekil 3'te "Dinleme/izleme becerisinin ölçme ve değerlendirmesi" boyutuna ilişkin temalar şema hâlinde gösterilmiştir. 


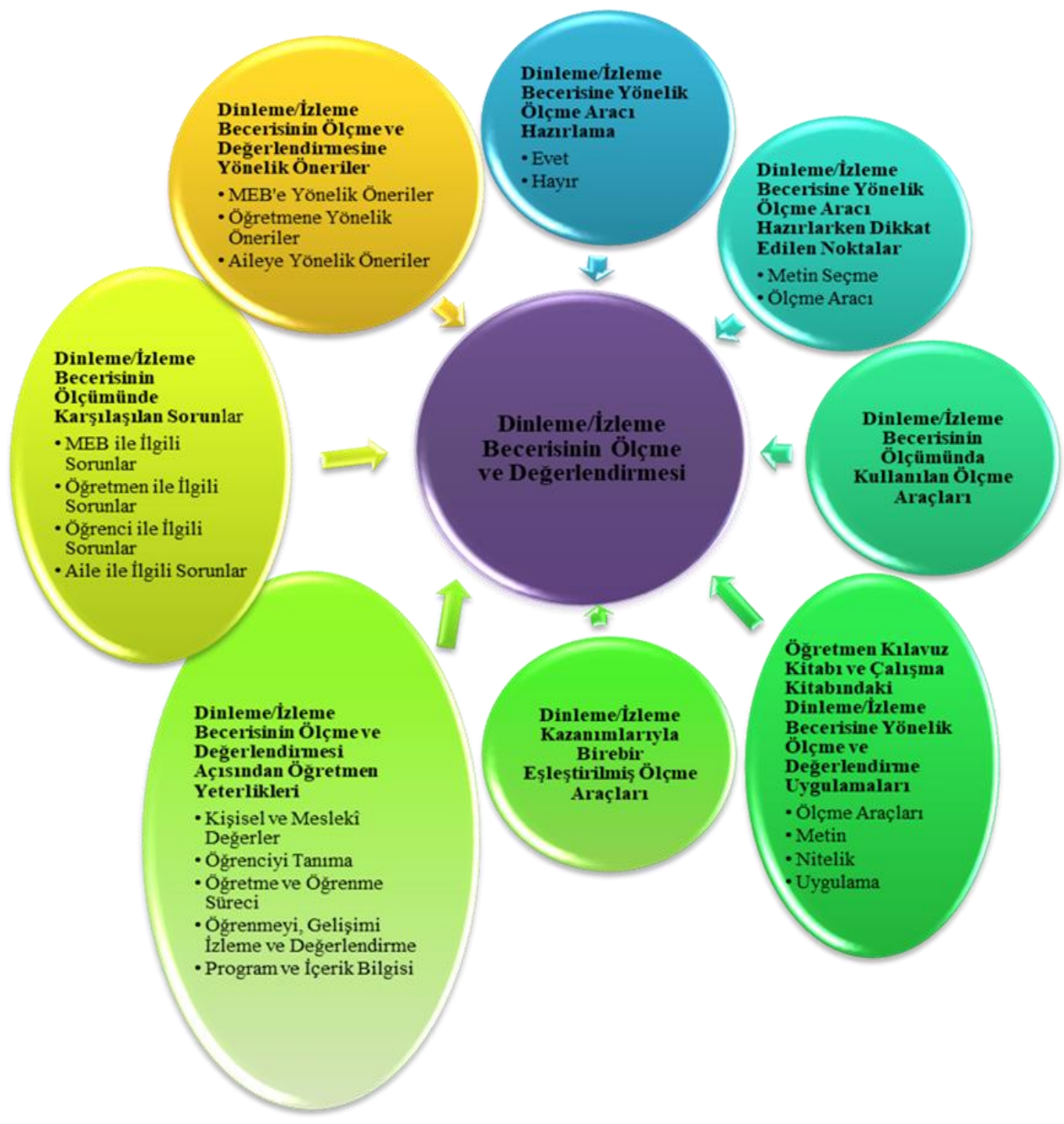

Şekil 3. Dinleme/izleme becerisinin ölçme ve değerlendirmesi

\section{Tartışma, Sonuç ve Öneriler}

\section{Türkçe Eğitiminin Ölçme ve Değerlendirmesine Iliş̧in Sonuç ve Tartışma}

“Ölçme ve Değerlendirme Kavramlarına iliş̧kin Bulgular”da öğretmenlerin yarısından azının ölçme ve değerlendirme kavramlarına ilişkin doğru tanımlamalar yaptığı görülmektedir. Bu kadar az öğretmenin ölçme ve değerlendirme kavramlarını doğru tanımlayabilmesi düşündürücüdür. Öğretmenlerin çoğu lisans sürecinde ölçme ve değerlendirme dersi almışlardır. Kavramlar hakkında bilgileri olmayan kişilerin ölçme ve değerlendirme uygulamalarını nasıl yaptığı tartışılır bir durumdur. Ayrıca Türkçe öğretmenlerinin genel olarak ölçme ve değerlendirmeye yönelik yaklaşımlarının olumsuz olduğu görülmüştür.

"Türkçe Eğitiminde Ölçme ve Değerlendirmenin Kullanımına İlişkin Bulgular" da sürecin başında ölçme ve değerlendirmeyi kullanan öğretmen sayısı çok azdır. Öğrencilerin hazırbulunuşluğu belirlenmeden verilecek bir eğitimin amacına ne kadar ulaşacağı bilinemez. Çünkü ölçme ve 
değerlendirmenin en başta gelen amaçlarından biri öğrencinin başlangıçtaki durumuyla eğitim sonucundaki durumu arasındaki farkı görebilmektir. Öğretmenlerin yarısının öğrenciyi süreçte ve sürecin sonunda ölçüp değerlendirdiği görülmektedir. Öğretmenlerin yarısından fazlasının süreçte ölçme ve değerlendirmeyi kullanıp kullanmadığını belirtmemesi kullanmadıkları anlamına gelebilir. Öğretmenlerin çoğunluğu sürecin sonunda ölçme ve değerlendirmeyi kullandığını belirtmiştir. Ancak sürecin sonundaki ölçme ve değerlendirme amaçları ağılıklı olarak not vermedir. Öğretmenlerin sürecin tamamında ölçme ve değerlendirmeyi kullanmaktan ziyade sürecin sonunda not verme amacıyla kullanmaları, verdikleri eğitimin tespiti ve yapılacak çalışmalara yön verme konusunda eksikliklerin ortaya çıkmasına sebep olabilir. Ölçme ve değerlendirmenin sürece yayılması gerekir. Öğretim sürecinin sadece son basamağında kullanılması sürecin sağlıklı işlemesini engeller. Türkçe eğitiminde de başarıya ulaşabilmek için öğretmenlerin ölçme ve değerlendirmeyi sürecin tamamında kullanması gerekir.

“Türkçe Dersi Öğretim Programı ve Kitaplardaki Ölçme ve Değerlendirme Araçlarına İlişkin Bulgular"da öğretmenler performans ödevlerinin (performans görevleri) kaldırılmasından memnun olduklarını ve artık kullanmadıklarını dile getirmektedirler. Ağılıkı olarak belirttikleri kullanmama nedenleri ise ödevin kırtasiyede yapılması, öğrencinin ailesinin yapması, internetten yapması, faydalı olmamasıdır. Ancak bu gerekçeler öğretmenlerin performans ödevi yaptırmaması için makul gerekçeler değildir. Öz ve akran değerlendirmeyi öğretmenlerin kullanmama nedenleri ortak olup genellikle öğrenciden kaynaklanan; öğrencinin bilinçli olmaması, objektif olamaması ve gereksiz olması gibi nedenlerdir. Ancak bunlar öğrenciye öz ve akran değerlendirmenin yaptırılmaması için geçerli sebepler olamaz. Ortaokul çağındaki öğrencilerin tamamıyla objektif bir değerlendirme yapamamaları söz konusu olabilir. Ancak objektif bir değerlendirme yapabilmeleri için zamanla bu aşamalardan geçmeleri gerekmektedir. Öğretmenlerin gözlem, tutum ölçeği, dereceli puanlama anahtarı, görüşme gibi yöntemleri hiç kullanmadığı ve belki de bu araçlardan haberdar olmadığı veya araçları kullanmaları gerektiğinin farkında olmadıkları söylenebilir. Öğretmenlerin genellikle eskiden beri kullanılagelen ölçme araçlarını tercih ettikleri, çok azının tamamlayıcı ölçme araçlarını kullandığı belirlenmiştir. Öğretmenlerin çoktan seçmeli ve açık uçlu sorulara yönelmesi sürekli dile getirilen yapılandırıcı anlayıştan ziyade yıllardır süregelen geleneksel ölçme ve değerlendirme yaklaşımlarının devam ettiğinin göstergesidir. Çok az öğretmen bu anlayışı kırabilmiştir.

Bullens (2002) araştırmasında hâli hazırda kullanılmakta olan değerlendirme metotları ile ilgili yaşanan sorunların öğrencilerin hissetmiş oldukları sınav kaygısı, bir konu ile ilgili olarak öğrencilerin sahip oldukları bilgileri yansıtmayan bir puanlama sistemi, öz değerlendirme eksikliği ve ölçüt geliştirmede öğrencilerin sürece dâhil edilmemesi olduğunu belirtmiştir. Bu durum öğretmenlerin tamamlayıcı ölçme ve değerlendirme araçlarını kullanmadıklarını ortaya koymuştur. Bu araştırmada da 
Türkçe Öğretmenlerinin Anlama Becerilerinde Ölçme ve Değerlendirmeye Yönelik Görüşleri

öğretmenlerin tamamlayıcı ölçme ve değerlendirme araçlarını kullanmamalarının ve öğrencilerin yapmak istememelerinin sebebi sınav sistemine yönelik hazırlanmak istemeleri, sınavın getirdiği kaygı olabilir.

“Dil Alanlarına Göre Ayrı Ayrı Puanlamaya İlişkin Bulgular"da öğretmenlerin büyük çoğunluğu ayrı ayrı puanlama yapmadığını belirtirken çok azı ayrı ayrı puanlama yaptığını dile getirmiştir.

\section{Okuma Becerisinin Ölçme ve Değerlendirmesine İlişkin Sonuç ve Tartışma}

“Okuma Becerisine Yönelik Ölçme Aracı Hazırlamaya Illişkin Bulgular”da öğretmenlerin çoğu ölçme aracı hazırladığını belirtirken bir kısmı hazırlamadığını ifade etmiştir. Hazırlamayan öğretmenlerin süreçte ve yazılılarda ne kullandıkları tartışııır bir durumdur. Öğretmenlerin okuma becerisine yönelik ölçme aracı hazırlamasının sebebi ise süreçten ziyade sürecin sonundaki yazılılardır. Bunlar da genellikle kısa bir metin ve metne yönelik sorulardır. Karakoç Öztürk'ün (2008) araştırmasında da öğretmenler ağırlıklı olarak öğretmen kılavuz kitabında yer alan etkinlikler dışında etkinlik geliştirmediklerini belirtmişlerdir.

“Okuma Becerisine Yönelik Ölçme Aracı Hazırlarken Dikkat Edilen Noktalara İlişkin Bulgular”da öğretmenler metin seçmede de, ölçme aracı hazırlamada da sınıfın düzeyine uygun olmasına dikkat ettiklerini belirtmişlerdir. Ancak sınıf düzeyine uygunluk göreceli bir kavramdır. Bu konuda Türkçe eğitiminde net kriterler ortaya konması gerekmektedir. Öğretmen sınıfındaki öğrencileri iyi tanımasıyla seviye algısına göre bir metin seçebilir ve ona yönelik araç geliştirebilir. Öğretmenlerin de belirttiği gibi ölçme aracı hazırlamadan önce ilk yapılması gereken iyi bir metin seçme işlemidir. Ozuru, Rowe, O'Reilly, McNamara (2008) da yaptıkları araştırmada soruların zorluğunun 7, 8 ve 9. sınıf öğrencileri için birincil olarak metin özellikleri özellikle de kelime güçlüğü tarafından belirlendiğini ifade etmişlerdir.

“Okuma Becerisinin Ölçümünde Kullanılan Ölçme Araçlarına Illişkin Bulgular”da öğretmenler ağırlıklı olarak okuma becerisinin ölçümünde açık uçlu ve kısa cevaplı soruları tercih ettiklerini ifade etmişlerdir. Sebebi olarak da öğrencinin düşüncelerini ifade etmesini istediklerini belirtmişlerdir. Ancak öğretmen kılavuz kitabında da metin altı sorular genellikle kısa cevaplı ve açık uçludur. Öğretmenler her metinden sonra yer aldığı için en çok bu tür soruları kullandıklarını belirtmiş olabilirler. Karakoç Öztürk'ün (2008) araştırmasında öğretmenler açık uçlu soruları ağılıklı olarak kullandıklarını belirtmişlerdir. Bu durum araştırmanın bulgularıyla örtüşmektedir. Ancak öğretmenlerin tamamlayıcı ölçme ve değerlendirme yaklaşımlarını da ağırlıklı olarak kullandıklarını belirtmeleri bu araştırmanın bulgularıyla örtüşmemektedir. Ayrıca öğretmenlerin öz değerlendirme, akran değerlendirme, grup değerlendirme gibi araçları objektif bulmamaları da araştırmanın bulgularını desteklemektedir. 
“Öğretmen Kılavuz Kitabı ve Çalışma Kitabındaki Okuma Becerisine Yönelik Ölçme ve Değerlendirme Uygulamalarına Iliş̧kin Bulgular"da öğretmenlerin en fazla rahatsız oldukları durum metinlerdir. Metinlerin öğrenci seviyesine uygun olmaması ve uzun olmasından şikâyet etmektedirler. Batur, Gülveren, Bek (2010) de ders kitaplarında yer alan metinlerin okuma alışkanlığını kazandıracak nitelikte hazırlanması, öğrencilerin yaş ve ilgi düzeylerinin dikkate alınması gerektiğini belirtmişlerdir. Ayrıca öğretmenlerin çoğunluğu araçların niteliğini yetersiz bulmakta ve yayınevine göre kitapların değişmesinden rahatsız olduklarını belirtmektedirler. Uygulamaya yönelik görüş bildirenlerin de çoğu olumsuz durumlardan bahsetmişlerdir. Çok zaman alması, uygulanabilir olmaması gibi nedenlerle ölçme araçlarını ya seçerek kullandıklarını ya da hiç kullanmadıklarını ifade etmişlerdir. Karakoç Öztürk'ün (2008) araştırmasında ise öğretmenler öğretmen kılavuz kitabında yer alan etkinlikleri her zaman ve sık sık uyguladıklarını ancak uygulama için zamanın yeterli olmadığını belirtmektedir. Bu araştırmayla öğretmenlerin kılavuz kitaptaki uygulamaları kullanma durumu çelişirken zamanın yeterli olmaması durumu uyuşmaktadır.

“Okuma Kazanımlarıyla Birebir Eşleştirilmiş Ölçme Araçlarına ilişskin Bulgular”da olumlu görüşten ziyade olumsuz görüş yer almaktadır. Öğretmeni yönlendirmesi ve yeterli olması yönüyle olumlu açıdan değerlendirilmiştir. Ancak olumsuz görüş bildiren öğretmenlerin çoğunluğu bu araçları uygulamadıklarını, yaptırmadıklarını dile getirmişlerdir. Kendilerine sunulan araçları kullanmayan hem de ölçme aracı hazırlamayan öğretmenlerin yazılılar dışında nasıl ölçme ve değerlendirme yaptığı veya yapıp yapmadığı tartışııı bir durumdur. Türkçe eğitimi beceri ve kazanım temelli yürütülmektedir. Öğrencilerin bu kazanımlara ulaşıp ulaşmadığını kontrol etmenin en iyi yolu kazanımlara yönelik ölçme araçlarıdır. Bu olmadığı takdirde başarıı bir süreç yürütülemeyeceği aşikârdır.

“Okuma Becerisinin Ölçme ve Değerlendirmesi Açısından Öğretmen Yeterliklerine İlişkin Bulgular"da MEB öğretmen yeterliklerine göre altı tema ortaya çıkmıştır. Öğretmenler ağılıklı olarak bir öğretmenin iyi bir okuyucu olması, okuduğunu anlaması ve yorumlaması, yayınlardan haberdar olması, kazanımları önce kendisinin gerçekleştirmiş olması, öğrencinin seviyesine uygun metinler seçmesi, öğrencilere onların yaşına ve ilgisine hitap eden kitaplar önermesi, örnek okuma yapması, bir metni veya kitabı okumayı öğretmesi, alanına hâkim olması gerektiğini belirtmişlerdir. Ancak okuma becerisinin ölçme ve değerlendirmesi açısından doğrudan önem teşkil eden öğrenciyi, gelişimi izleme ve değerlendirme temasına ilişkin ise bir öğretmenin okuma düzeyini tespit etmek için öğrenciyi gözlemlemesi, öğrencinin okuduğunu anlayıp anlamadığını değerlendirmesi, öğrencilere okuduğunu anlamaya yönelik değerlendirme soruları sorması gerektiğini ifade etmişlerdir.

“Okuma Becerisinin Ölçümünde Karşılaşılan Sorunlara İlişkin Bulgular”da dört tema ortaya çıkmıştır. Öğretmenler hem kendileri hem de MEB'le ilgili temada sınıfların kalabalık olmasının ölçme ve değerlendirmeye zaman ayıramamalarına sebep olduğunu belirtmişlerdir. Öğrenciler ile ilgili 
yaşadıkları en önemli sorunlar, öğrencinin okuma güçlüğü olması ve o öğrenciye okuma yaptırıldığında akranlarının müdahalesi sonucu öğrencinin bu durumdan olumsuz etkilenmesidir. Ayrıca öğretmenler öğrencilerin okuma alışkanlıklarının olmaması ve dikkatini dağıtan şeyler yüzünden okumayı sevmemesinden de yakınmaktadır. Öğretmenler ağırlıklı olarak okuma becerisinin ölçümünde karşılaştıkları temel sorunları öğrencilere bağlamışlardır. Bu sorunların olması normaldir. Önemli olan öğretmenlerin bunlara yönelik çözümler bulabilmesidir. Bunların yanı sıra ailenin de üzerine düşen görevi yapmaması sorunların iyice büyümesine neden olmaktadır. Johnsson-Smaragdia, Jönsson (2006) da görsel ve bilgi teknolojileri araçlarının boş zamanda kitap okumanın karşısındaki en büyük tehdit olarak görüldüğünü, bu araçların daha yaklaşılabilir alternatifler sunarak çocukların ve gençlerin ilgisini okumadan uzaklaştırmakla suçlandığını belirtmektedir.

Yapılan bir araştırmada (Draper, Barksdale-Ladd, Radencich, 2000) öğretmen adaylarının hiç birisi, gelecekteki öğrencilerinde okuma sevgisini geliştirmek için önerilerde bulunamamıştır. Bu araştırmada da öğretmenler ağırlıklı olarak öğrencilerin okuma sorunlarını dile getirmişler ancak bu durumda bir öğretmenin neler yapabileceğine ilişkin öğretmen yeterliklerinde ve önerilerde görüş belirtmemişlerdir. Bu durum öğretmenlerin lisans düzeyinde aldıkları eğitimin teoride kaldığını, uygulamaya dönüşebilmesi için öğretmenlere eğitim verilmesi gerektiğini ortaya çıkarabilir.

“Okuma Becerisinin Ölçme ve Değerlendirmesine Yönelik Önerilere İlişkin Bulgular"da öğretmenler ağırlıklı olarak sınıf mevcudunun azaltılmasını ve metinlerin gözden geçirilerek ağırlıklı olarak hikâye edici metinlere yer verilmesini istemektedirler. Belirtilen bulgular okuma becerisinin ölçümünde ağırlıklı olarak karşılaşılan sorunlara ilişkin bulgularla örtüşmektedir. Karakoç Öztürk'ün (2008) araştırmasında da öğretmenler ders kitaplarında yer alan hikâye, efsane gibi hikâye edici metinlerin öğrenciler için daha uygun olduğunu belirtmişlerdir. Bu durum araştırmanın bulgularıyla uyuşmaktadır.

Applegate ve Applegate'in (2004) öğretmen adayları üzerine yaptığı araştırmada öğretmen adayları geçmişte almış oldukları okuma eğitiminden olumlu ve olumsuz yönde etkilendiklerini belirtmişlerdir. Öğretmen adaylarının çoğu geçmişte almış oldukları okuma eğitimini "sıkıcı kitapları okumak" ve "kitap raporları oluşturmak" veya "okumayı ilginç bir hâle getiremeyen öğretmenler" tarafından öğrenim görme olarak hatırlamaktadır. Ayrıca, okumayı öğrenirken en zayıf okuma grubuna koyulmak, öğrenme özürlü olarak etiketlenmek veya gereksinim duydukları yardımı alamamak gibi gerçekleştirdikleri mücadeleleri hatırlamışlardır. Olumlu yönde görüş bildiren öğretmen adayları okuma eğitimi ile ilgili eğlenceli, iyi kitapları ve ne okunması gerektiği ile ilgili bilgileri paylaşan öğretmenleri, aldıkları destekleri, öğretmenlerinin ve ailelerinin onların başarılarından duydukları gururu hatırlamaktadırlar. Bu araştırmada da öğretmenler öğrencilerin temelden okuma alışkanlığı kazanmamış olmalarının ve okumaları esnasında akranları tarafından müdahale edilmesinin öğrenciyi 
okuma becerisi ve ölçme değerlendirmesi açısından olumsuz etkilediğini belirtmişlerdir. Bu olumsuzlukların giderilmesi için öğretmen, öğrenci ve veli iş birliği içinde olmalıdır. Arıcı (2008) da ailenin okuma becerisinin gelişiminde model olduğunu vurgulamaktadır. Araştırmada aileye yönelik öneri ve aileden kaynaklanan sorunların az olması temelde olumlu bir durumdur. Ancak okumaya yönelik pek çok sorundan söz eden öğretmenlerin aileye yönelik önerilerinin özellikle okuma alışkanlığı kazanmada ağılık kazanması beklenirdi.

Dinleme/Izleme Becerisinin Ölçme ve Değerlendirmesine ilişkin Sonuç ve Tartışma

“Dinleme/İzleme Becerisine Yönelik Ölçme Aracı Hazırlamaya İlişkin Bulgular”da öğretmenlerin çoğunluğu ölçme aracı hazırlamadığını belirtirken çok azı hazırladığını ifade etmiştir. Ancak ölçme aracı hazırlamayanların çoğu niçin hazırlamadığına ilişkin bilgi vermemiştir. Öğretmenlerin dinleme/izleme becerisine yönelik ölçme aracı hazırlamamasının sebebi ağırlıklı olarak ölçme araçlarının kılavuz kitapta olmasıdır. Öğretmenlere bir şeylerin hazır verilmesi öğretmenlerin öğrencilerine uygun yeni araçlar hazırlamamasına sebebiyet vermiş olabilir. Ayrıca çoğu açıdan öğretmen kılavuz kitabını yetersiz bulan ve olumsuz görüş bildiren öğretmenlerin burada kılavuz kitabı kullandıklarını belirtmeleri düşündürücüdür. Dinleme/izleme becerisinde ölçme aracı hazırlamaya ilişkin okumanın tersine bir durum söz konusudur. Bu durum öğretmenlerin en azından yazılılarda okuma becerisini ölçmek için araç hazırlamalarından dinleme/izleme becerisini ise ne yazılıda ne de süreçte ölçmemelerinden kaynaklanmaktadır.

“Dinleme/İzleme Becerisine Yönelik Ölçme Aracı Hazırlarken Dikkat Edilen Noktalara Iliş̧kin Bulgular"da öğretmenler metin seçmede öğrencinin ilgisini çekmesine ölçme aracında ise metnin önemli noktalarından soru sormaya dikkat ettiklerini belirtmişlerdir. Hâlbuki "Okuma Becerisine Yönelik Ölçme Aracı Hazırlarken Dikkat Edilen Noktalara illişkin Bulgular"da öğretmenler metin seçmede ve ölçme aracında sınıfın düzeyine uygun olmasına dikkat ettiklerini ifade etmişlerdir.

“Dinleme/İzleme Becerisinin Ölçümünde Kullanılan Ölçme Araçlarına ílişkin Bulgular”da öğretmenler ağırlıkı olarak okuma becerisinin ölçümünde de olduğu gibi açık uçlu ve kısa cevaplı soruları tercih ettiklerini ifade etmişlerdir. Sebebi olarak da öğrencinin düşüncelerini ifade etmesi gerektiğini belirtmişlerdir. Öğretmenlerin dinleme/izleme becerisinde de ölçme araçlarının çeşitliliğine dikkat etmediği görülmektedir. Kurt'un (2008) araştırmasında ise öğretmenler öğrencilerinin dinleyip dinlemediğini arkadaşının söylediğini tekrarlatarak, derse başladığında söylediklerini tekrarlatarak ölçtüğünü belirtmektedir.

Incelenen araştırmalar doğrultusunda dinleme ve okuma becerilerinin başarı ölçümünde ağırlıklı olarak çoktan seçmeli ve açık uçlu soruların kullanıldığı görülmektedir. Bu durum başarı ölçümünün bir kısır döngü hâlinde devam etmesine, öğrencilerin farklı ölçme araçlarına uyum 
sağlayamamasına neden olabilir. Doğan (2011) da farklı ölçme araçlarının kullanılmasının öğrencilerin derse karşı ilgisini ve ilgili eğitim çalışmalarından alınacak verimi artıracağını ifade etmektedir.

“Öğretmen Kılavuz Kitabı ve Çalışma Kitabındaki Dinleme/İzleme Becerisine Yönelik Ölçme ve Değerlendirme Uygulamalarına İlişkin Bulgular"da öğretmenler kitaplardaki ölçme araçlarına yönelik ağırlıklı olarak olumsuz görüş bildirmişlerdir. Öğretmenlerin çoğu da dinleme/izleme becerisine yönelik ölçme aracı hazırlamadığını ifade etmiştir. Hem olumsuz görüş bildirip dinleme/izleme ölçme araçlarını kullanmayan hem de kendisi ölçme aracı hazırlamayan öğretmenlerin dinleme/izleme becerisinin ölçümünü nasıl yaptıkları veya yapıp yapmadıkları tartışıı bir durumdur. Ölçme araçlarının birbirini tekrar etmesi ve bazılarının etkinlik sayısını artırmak için konulmuş olması öğretmenlerin belirttikleri olumsuz durumlardır. Metinlere yönelik görüş belirten öğretmenlerin büyük kısmının görüşü olumsuzdur. Hatta okumada da olduğu gibi öğretmenlerin en fazla rahatsı oldukları durum metinlerdir. Gündoğdu (2011) da bir yayınevine ait ders kitabındaki metinlerin büyük çoğunluğunda karamsarlık, şiddet, argo, insanî değerlere aykırılık içeren anlatımların var olduğunu belirtmektedir. Ayrıca öğretmenler uzun metinlerin ve düşünce yazılarının olmasından şikâyet etmektedirler. Yıldırım ve diğerlerinin (2010) yaptıkları araştırmada da öğrencilerin dinledikleri ve okudukları bilgi verici metni anlama düzeyleri arasında anlamlı bir farklılık olmadığı, hem okumada hem de dinlemede öyküleyici metnin bilgi verici metinden daha iyi anlaşıldığı görülmüştür. Bu araştırmada da öğretmenler hem okumada hem de dinlemede hikâye edici metinlerin öğrenciler tarafından daha iyi anlaşıldığını, ders kitaplarında hikâye edici metinlere ağırlıklı şekilde yer verilmesi gerektiğini belirtmişlerdir. Ayrıca öğretmenlerin bir kısmı dinleme/izleme açısından ölçme ve değerlendirme uygulamalarını yeterli bulmaktadır. Buna karşıık çoğu öğretmen de yetersiz bulmakta ve durumun yayınevine göre değişmesinden rahatsız olduklarını belirtmektedirler. Uygulamaya yönelik görüş bildirenlerin ifadelerinden öğretmenlerin büyük kısmının dinleme/izleme becerisini ölçmedikleri gibi dinleme/izleme bile yaptırmadıkları anlaşılmaktadır. Aslında öğretmenlerin çoğu iyi yazılmış bir kitap kendilerine verildiğinde ölçme ve değerlendirme de dâhil olmak üzere eğitim sürecinin çok iyi ilerlediğini ifade etmektedirler.

“Dinleme/İzleme Kazanımlarıyla Birebir Eşleştirilmiş Ölçme Araçlarına iliş̧in Bulgular”da olumlu görüşten ziyade olumsuz görüş yer almaktadır. Burada da okuma becerisinde olduğu gibi öğretmenlerin çoğu dinleme/izleme kazanımlarıyla birebir eşleştirilmiş ölçme araçlarını kullanmadıklarını veya seçerek kullandıklarını belirtmişlerdir. Ayrıca öğretmenlerin büyük çoğunluğu görüşme sürecinde derste dinleme/izleme uygulamaları yaptırmadığını da dile getirmiştir.

“Dinleme/İzleme Becerisinin Ölçme ve Değerlendirmesi Açısından Öğretmen Yeterliklerine illişkin Bulgular"da öğretmenlerin, bir öğretmenin öncelikle iyi bir dinleyici olması, iyi bir okuyucu olması, öğrenciyi dinleme için güdüleyebilmesi, öğrenci seviyesine göre metinler seçmesi, ders 
kitaplarından başka materyaller kullanması, alanına hâkim olması gerektiği yönündeki görüşleri okuma becerisindeki bulgularla örtüşmektedir. Dinleme/izleme becerisinin ölçme ve değerlendirmesiyle doğrudan ilişkili olan öğrenmeyi, gelişimi izleme ve değerlendirme temasına yönelik ağırlıklı olarak bir öğretmenin öğrencinin dinleyip dinlemediğini ölçmesi, metinle ilgili sorular sorması, hazırladığı ölçme aracının maddelerinin amaca hizmet etmesi gerektiği görüşleri öne çıkmıştır.

“Dinleme/İzleme Becerisinin Ölçümünde Karşılaşılan Sorunlara Illişkin Bulgular"da üç tema ortaya çıkmıştır. Öğretmenler sınıfların kalabalık olmasının ve sınıfın fizikî imkânlarının dinleme/izleme becerisinin ölçme ve değerlendirmesine engel olduğunu ifade etmişlerdir. Öğretmenler ayrıca dinleme/izleme becerisini ölçememekten ve ölçümünün zaman almasından şikâyet etmektedirler. Okuma becerisinde de olduğu gibi öğrencilerle ilgili sorun bildiren öğretmen sayısı fazladır. Öğrencilerle ilgili en fazla yakınılan durumlar dinleme/izlemede öğrencinin dikkatinin dağılması ve öğrencinin dinlememesidir. Bu becerinin kazandırılma amacı öğrenciyi hayata hazırlamaktır. Öğrencinin uzun bir süre dinleme/izlemesi gereken durumlar olacaktır. Dikkatin dağılması ölçmeme açısından geçerli bir mazeret değildir. Alonso ise (1996) yedinci sınıf öğrencileriyle gerçekleştirdiği araştırmada öğrencilerin dinleme becerilerinde görülen yetersizliklerinin sebebinin öğrencilerin konuşmacının mesajlarına olan ilgisizliği ve pasifliği, zayıf iletişime yol açan güven eksikliği olduğunu belirlemiştir. Ayrıca öğrencilerde sınıf ortamında gerçekleştirilen pasif dinlemede sıkıntı ve motivasyon eksikliği görülmüştür.

“Dinleme/İzleme Becerisinin Ölçme ve Değerlendirmesine Yönelik Önerilere Illişkin Bulgular”da öğretmenler ağırlıklı olarak metinlerin değişmesini, hikâye edici metinlere yer verilmesini, uygun bir dinleme ortamının sağlanmasını, öğrenci sayısının azaltılmasını istemektedirler. Bu öneriler okuma becerisine yönelik önerilerle örtüşmektedir. İki beceride de en fazla değinilen durum metinlerin değişmesidir. Çelebi (2008) de 6, 7, 8. sınıflarda yaptığı araştırmada öğrencilerin olay yazılarına dayalı dinlediğini anlama düzeylerinin düşünce yazılarını anlama düzeylerinden daha yüksek olduğunu belirtmektedir.

Öğretmenlerin dinleme/izleme becerisinin ölçme ve değerlendirmesine yönelik görüşlerine bakıldığında çoğunun dinleme/izleme eğitimi vermedikleri dolayısıyla ölçme ve değerlendirmesini yapmadıkları görülmektedir. Kuşçu (2010) da araştırmasında anlatım (konuşma ve yazılı anlatım) alt boyutlarının anlama (dinleme ve okuma) alt boyutlarına göre öğretmenler tarafından daha kolay uygulanabildiğini, dinleme ve okuma becerileri üzerinde yeterince durulmadığını göstermektedir. Bu durum dinleme/izleme becerisi açısından araştırmanın bulgularıyla örtüşmektedir.

Türkçe eğitimi ve anlama becerilerinde ölçme ve değerlendirmeye yönelik araştırmalar 2000'li yıllardan bu yana ivme kazanarak artmaktadır. Ancak yapılan araştırmaların birbiriyle benzer nitelikte olduğu görülmektedir. Türkçe eğitiminde kullanılacak ölçme araçlarının çeşitlendirilmesi; öğrencilerin 
monotonluktan kurtulması, sınavlardaki aynı tip sorulardan bıkmalarının engellenmesi, öğretim süreci ve çıktılarının daha iyi değerlendirilebilmesi, öğrencilerin ölçme ve değerlendirme sürecinin içine alınması, süreçle ilgili öğrencilere dönütler verilmesi açısından yarar sağlayacaktır.

Araştırmanın sonuçları doğrultusunda şu önerilerde bulunulabilir: Kitaplarda yayınevlerine göre oluşan farklılaşmalar en aza indirilmelidir. Ölçme araçlarının öğretmenler tarafından belirtilen olumsuz yönlerinin nasıl giderilebileceğine veya ölçme araçları hangi durumlarda kullanıldığında bu sorunların aşılabileceğine yönelik kılavuz kitaplarda açıklamalar yapılmalıdır. Kazanımların birebir ölçümüne yönelik çeşitli ölçme araçları geliştirilmelidir. Kazanımlardan beklenenin ne olduğuna ilişkin kazanım ifadeleri derinleştirilerek ölçümüne ilişkin açıklamalar eklenmelidir. Öğretmenlerden alınan dönütlere göre kitap baskılarında düzeltmeler yapılmalıdır. Dil becerilerinin bütün yönleriyle öğrenci ve öğretmen açısından önem arz etmesi için dinleme/izleme, konuşma ve yazma becerileri de ölçülmelidir. Öğretmenlere Türkçe eğitiminde ölçme ve değerlendirmenin kullanımına ilişkin eğitim verilmelidir. Öğretmenlerle kazanımlar üzerine tek tek konuşularak neler yaptıkları hakkında bilgi alınmalı, neler yapabilecekleri hangi kazanım için hangi ölçme araçlarını kullanabileceklerine dair öğretmenler bilgilendirilmelidir. Öğretmenler ölçme aracı hazırlamaya teşvik edilmeli, öğretmen kılavuz kitaplarında ölçme ve değerlendirme konusunda öğretmenleri yönlendirecek ayrıntılı bilgilere yer verilmelidir.

\section{Kaynaklar}

Acar, Ö. (2012). ilköğretim ikinci kademe Türkçe öğretiminde proje ve performans görevlerinin işlevselliği ile ilgili bir araştırma (Kars îli örneği). Yüksek Lisans Tezi, Erzincan Üniversitesi Sosyal Bilimler Enstitüsü, Erzincan.

Adıyaman, Y. (2005). İlköğretim 4, 6 ve 8. sınıflarında Türkçe dersine giren öğretmenlerin ölçme-değerlendirme düzeyleri. Yüksek Lisans Tezi, Afyon Kocatepe Üniversitesi Sosyal Bilimler Enstitüsü, Afyon.

Akyol, H. (2007). Okuma. A. Kırkkılıç, H. Akyol (Ed.), Illöğretimde Türkçe öğretimi (ss. 15-48). Ankara: Pegem.

Alonso, L. (1996). Improving deficient listening skills in the language arts program at the middle grades. Master Dissertation, Saint Xavier University.

Applegate, A. J., Applegate, M. D. (2004). The Peter effect: Reading habits and attitudes of preservice teachers. The Reading Teacher, 57(6), 554-563.

Arıcı, A. F. (2008). Okumayı niye sevmiyoruz? Üniversite öğrencileri ile mülakatlar. Mustafa Kemal Üniversitesi Sosyal Bilimler Enstitüsü Dergisi, 5(10), 91-100.

Arslan, A. (2013). Türkçe öğretmenlerinin proje ve performans ödevleri ile ilgili görüşlerinin değerlendirilmesi. Dil ve Edebiyat Eğitimi Dergisi, 2(6), 11-22.

Atılgan, H., Kan A., Doğan, N. (2006). Eğitimde ölçme ve değerlendirme. Ankara: Anı.

Batur, Z., Gülveren, H., Bek, H. (2010). Öğretmen adaylarının okuma alışkanlıkları üzerine bir araştırma: Uşak Eğitim Fakültesi örneği. Uşak Üniversitesi Sosyal Bilimler Dergisi, 3(1), 32-49.

Baykul, Y. (2010). Eğitimde ve psikolojide ölçme. Ankara: Pegem.

Benzer, A., Eldem, E. (2013). Türkçe ve edebiyat öğretmenlerinin ölçme ve değerlendirme araçları hakkında bilgi düzeyleri. Kastamonu Eğitim Dergisi, 21(2), 649-664.

Berg, B. L. (2004). Qualitative research methods for the social sciences. USA: Pearson Education. 
Beyhan, S. (2012). Türkçe öğretmenlerinin ölçme ve değerlendirme uygulamalarına ilişkin görüşleri (Düzce ili örneği). Yüksek Lisans Tezi, Abant İzzet Baysal Üniversitesi Eğitim Bilimleri Enstitüsü, Bolu.

Black, P., Harrison, C., Lee, C., Marshall, B., William, D. (2003). Assessment for learning. USA: Open University.

Buck, G. (2001). Assessing listening. Cambridge: Cambridge University.

Bullens, D. (2002). Authentic assessment: Change for the future. Master Theses, Saint Xavier University.

Çakmak Akata, A. (2009). Türkçe Programılla ilgili ölçme ve değerlendirme sürecinin işlevselliği üzerine bir araştırma (Tekirdağ ili örneği). Yüksek Lisans Tezi, Abant İzzet Baysal Üniversitesi Sosyal Bilimler Enstitüsü, Bolu.

Çelebi, H. M. (2008). Illköğretim 6, 7 ve 8. sınıf öğrencilerinin olay ve düşünce yazılarına göre dinleme becerilerinin değerlendirilmesi (Muğla örneği). Yüksek lisans tezi, Muğla Üniversitesi Sosyal Bilimler Enstitüsü, Muğla.

Doğan, Y. (2011). Dinleme eğitimi. Ankara: Pegem.

Draper, M. C., Barksdale-Ladd, M. A., Radencich, M. C. (2000). Reading and writing habits of preservice teachers. Reading Horizons, 40(3), 185-203.

Erkuş, A. (2006). Ölçme ve değerlendirme. Ankara: Ekinoks.

Ertürk, A., İ. (2008). Yenilenen ilköğretim Türkçe programlarındaki 6. sınıf okuma alanı hedefleri ile ilgili öğretmen görüşleri ve değerlendirilmesi. Yüksek Lisans Tezi, Afyon Kocatepe Üniversitesi Sosyal Bilimler Enstitüsü, Afyon.

Francis, D. J., Fletcher, J. M., Catts, H. W., Tomblin, J. B. (2005). Dimensions affecting the assessment of reading. S. G. Paris, S. A. Stahl (Eds.), Children's reading comprehension and assessment (pp. 369-394). New Jersey: Lawrence Erlbaum Associates, Inc.

Göçer, A. (2005). Ilköğretim II. kademe Türkçe öğretiminde ölçme ve değerlendirme. Doktora Tezi, Atatürk Üniversitesi Sosyal Bilimler Enstitüsü, Erzurum.

Göçer, A. (2007a). İlköğretim I. kademe Türkçe öğretiminde ölçme ve değerlendirme çalışmaları. Bilim ve Aklın Aydınlığında Eğitim, 94, 43-52.

Göçer, A. (2007b). İlköğretim Türkçe programlarında ölçme ve değerlendirmenin önemli bir boyutu olarak süreç değerlendirme. Öğretmen Dünyası, 334, 7-9.

Göçer, A. (2007c). Türkçenin yabancı dil olarak öğretiminde kullanılan ders kitaplarının ölçme ve değerlendirme açısından incelenmesi. Dil Dergisi, 137, 30-46.

Göçer, A. (2008a). İlköğretim Türkçe ders kitaplarının ölçme ve değerlendirme açısından incelenmesi. Atatürk Üniversitesi Sosyal Bilimler Enstitüsü Dergisi, 11, 197-210.

Göçer, A. (2008b). Performans göreviyle ilgili sunum çalışmalarının konuşma ve dinleme becerilerinin geliştirilmesine katkısı. Dil Dergisi, 142, 7-17.

Göğüş, B. (1978). Orta Dereceli Okullarımızda Türkçe ve Yazın Eğitimi. Ankara: Kadıoğlu.

Güler, N. (2011). Eğitimde ölçme ve değerlendirme. Ankara: Pegem.

Gündoğdu, A. E. (2011). İlköğretim sekizinci sınıf dinleme metinlerinin çeşitli değişkenler açısından incelenmesi. Turkish Studies, 6(1), 1186-1196.

Hogan, T. P. (2007). Educational assessment. USA: John Wiley \& Sons, Inc.

Johnsson-Smaragdia, U., Jönsson, A. (2006). Book reading in leisure time: Long-term changes in young peoples' book reading habits. Scandinavian Journal of Educational Research, 50(5), 519-540.

Karadüz, A. (2009). Türkçe öğretmenlerinin ölçme ve değerlendirme uygulamalarının "yapılandırmacı öğrenme" kavramı bağlamında eleştirisi. Uludağ Üniversitesi Eğitim Fakültesi Dergisi, 22(1), 189-210. 
Karakoç Öztürk, B. (2008). Ilköğretim altıncı sınıf Türkçe Dersi Öğretim Programı, okuma alanının öğretmen görüşlerine göre değerlendirilmesi. Yüksek Lisans Tezi, Çukurova Üniversitesi Sosyal Bilimler Enstitüsü, Adana.

Karip, E. (Ed.). (2008). Ölçme ve değerlendirme. Ankara: Pegem.

Kilmen, S. ve Beyhan, S. (2011). Türkçe öğretmenlerinin ölçme ve değerlendirme yöntemlerini uygulama sıklıkları ve tamamlayıcı değerlendirme yaklaşımlarına yönelik görüşleri (Düzce İli örneği). Ege Eğitim Dergisi, 12(2), 83-104.

Kurt, B. (2008). Çocuk edebiyatı ürünlerinin temel dil becerisi olarak dinlemenin gelişimine etkisi. Yüksek Lisans Tezi, Gazi Üniversitesi Eğitim Bilimleri Enstitüsü, Ankara.

Kuşçu, H. (2010). ilköğretim ikinci kademe öğrencilerinin dinleme, konuşma, okuma ve yazılı anlatım becerilerinin yapılandırıcı yaklaşıma göre geliştirilmesinde Türkçe öğretmeninin rolü. Yüksek Lisans Tezi, Yeditepe Üniversitesi Sosyal Bilimler Enstitüsü, İstanbul.

Linn, R. L., Gronlund, N. E. (1995). Measurement and assessment in teaching. USA: Prentice Hall.

Linn, R. L., Miller, M. D. (2005). Measurement and assessment in teaching. New Jersey: Pearson Education.

MacKay, I. (1997). Dinleme Becerisi. (Çev. A. Bora, O. Cankoçak). Ankara: Illkkaynak Kültür ve Sanat Ürünleri.

Maden, S., Durukan, E. (2011). Türkçe dersi öğretmenlerinin ölçme ve değerlendirmeye ilişkin algıları. Millî Eğitim, 190, 212-233.

Marshall, C., Rossman, G. B. (2006). Designing qualitative research. London: Sage Publications.

Melanlıoğlu, D. (2012). Dinleme becerisine yönelik ölçme değerlendirme çalışmalarında üstbiliş stratejilerinin kullanımı. Turkish Studies, 7(1), 1583-1595.

Melanlıoğlu, D., Karakuş Tayşi, E. (2013). Türkçe Öğretim Programındaki dinleme kazanımlarının ölçme değerlendirme yöntemleri bakımından sınıflandırılması. Dil ve Edebiyat Eğitimi Dergisi, 2(6), 23-32.

Merriam, S. B. (2013). Nitel araştırma (Çev. Ed. S. Turan). Ankara: Nobel.

Metin, M., Demiryürek, G. (2009). Türkçe öğretmenlerinin yenilenen Türkçe Öğretim Programlarının ölçmedeğerlendirme anlayışı hakkındaki düşünceleri. Ondokuz Mayıs Üniversitesi Eğitim Fakültesi Dergisi, 28, 37-51.

Miles, M. B., Huberman, A. M. (2015). Nitel veri analizi (Çev. Ed. S. Akbaba Altun, A. Ersoy). Ankara: Pegem.

Ozuru, Y., Rowe, M., O’Reilly, T., McNamara, D. S. (2008). Where's the difficulty in standardized reading tests: The passage or the question? Behavior Research Methods, 40(4), 1001-1015.

Özçelik, D. A. (2010a). Okullarda ölçme ve değerlendirme. Ankara: Pegem.

Özçelik, D. A. (2010b). Ölçme ve değerlendirme. Ankara: Pegem.

Payne, D. A. (2003). Applied educational assessment. USA: Thomson Wadsworth.

Pearson, P. D., Hamm, D. N. (2005). The assessment of reading comprehension: A review of practices-past, present, and future. S. G. Paris, S. A. Stahl (Eds.), Children's reading comprehension and assessment (pp. 13-70). New Jersey: Lawrence Erlbaum Associates.

Popham, W. J. (2005). Classroom assessment. USA: Allyn and Bacon.

Punch, K. F. (2005). Sosyal araştırmalara giriş (Çev. D. Bayrak, H. B. Arslan, Z. Akyüz). Ankara: Siyasal.

Reynolds, C. R., Livingston, R. B., Willson, V. (2010). Measurement and assessment in education. New Jersey: Pearson Education.

Tabak, G., Göçer, A. (2014). Dinleme becerisine yönelik alternatif ölçme ve değerlendirme araçları. Bartın Üniversitesi Eğitim Fakültesi Dergisi, 3(2), 250-272. 
Taylor, S. T., Nolen, S. B. (2005). Classroom assessment. New Jersey: Pearson Education.

Tekin, H. (1996). Eğitimde ölçme ve değerlendirme. Ankara: Yargı.

Türnüklü, A. (2000). Eğitimbilim araştırmalarında etkin olarak kullanılabilecek nitel bir araştırma tekniği: Görüşme. Kuram ve Uygulamada Eğitim Yönetimi, 24, 543-559.

Valencia, S. W., Pearson, P. D. (1988). Principles for classroom comprehension assessment. Remedial and Special Education, 9, 26-35.

Yıldırım, A. (1999). Nitel araştırma yöntemlerinin temel özellikleri ve eğitim araştırmalarındaki yeri ve önemi. Eğitim ve Bilim Dergisi, 23, 7-17.

Yıldırım, A., Şimşek, H. (2011). Sosyal bilimlerde nitel araştırma yöntemleri. Ankara: Seçkin.

Yıldırım, F., Karakoç Öztürk, B. (2009). Türkçe dersi öğretim programının ölçme değerlendirme öğesi hakkında öğretmen görüşleri. Çukurova Üniversitesi Eğitim Fakültesi Dergisi, 3(37), 92-108.

Yıldırım, K., Yıldız, M., Ateş, S., Rasinsky, T. (2010). illköğretim beşinci sınıf Türk öğrencilerinin metin türlerine göre okuduğunu ve dinlediğini anlama düzeyleri. Kuram ve Uygulamada Eğitim Bilimleri, 10(3), 1859-1891.

Yiğit, F. (2013). Ilköğretim 6, 7 ve 8. Sınıf Türkçe Dersi Öğretim Programı́ndaki alternatif ölçme-değerlendirme yöntemlerine yönelik öğretmen görüşlerinin değerlendirilmesi. Yüksek Lisans Tezi, Karadeniz Teknik Üniversitesi Eğitim Bilimleri Enstitüsü, Trabzon.

Yiğit, F., Kırımlı, B. (2014). Türkçe öğretmenlerinin alternatif ölçme değerlendirme yöntemlerini uygulama biçimleri ve uygulamada karşılaştıkları sorunlar. Turkish Studies, 9(3), 1621-1639.

Zorbaz, K. Z. (2005). İlköğretim okulları ikinci kademe öğretmenlerinin ölçme ve değerlendirmeye ilişkin görüşleri ve yazılı sınavlarda sordukları sorular üzerine bir değerlendirme. Yüksek Lisans Tezi, Mustafa Kemal Üniversitesi Sosyal Bilimler Enstitüsü, Hatay.

\section{Extended Abstract}

\section{Introduction}

One of the basic components of education is assessment and evaluation. Assessment and evaluation are used in every stage of education. With the implementation of Turkish Language Arts Curriculum, the amount of research focusing on assessment and evaluation in the field of Turkish language arts teaching has increased. However, there is a paucity of research dealing with the investigation of assessment and evaluation at skill level. In order to help fill this void in the literature, the present study aims to investigate Turkish language arts teachers' opinions about assessment and evaluation of comprehension skills. In this line, the purpose of the study was set to be to investigate the opinions of Turkish language arts teachers about the measurement and evaluation of Turkish language arts teaching, reading skill and listening/monitoring skill.

\section{Method}

The current study is a qualitative study. A semi-structured interview protocol was used as a data collection instrument to gather detailed information. In the piloting of the interview protocol, 5 Turkish language arts teachers were involved and then the interview form was administered to 50 Turkish language arts teachers. Maximum variation sampling method, one of the purposive sampling methods, was employed to attain variety in terms of demographic features such as gender, type of the graduated high school, education level, length of service and cities where the teachers have worked. In the interview form, there are totally 23 questions, 5 of which aim to elicit information about the first objective of the study, 9 of which are directed towards the second objective of the study and 9 towards the third objective of the study. With the permissions of the participants, the interviews were tape-recorded and then transcribed. Thus, 234-page raw data were collected. The collected data were analyzed through content analysis, one of the qualitative data analysis methods.

\section{Result and Discussion}

The findings related to the assessment and evaluation in the dimension of Turkish language arts teaching revealed that most of the participants do not know the concepts of assessment and evaluation, they mostly use assessment and evaluation at the end of the process, most of them do not make use of the assessment and evaluation tools provided in Turkish Language Arts Curriculum and the textbooks and they do not conduct separate scorings for different learning fields.

The findings related to the assessment and evaluation in the dimension of reading skill revealed that most of the teachers prepare evaluation tools to separately asses reading skill and pay attention to the level of 
their students and they use open-ended and short-answer questions in the assessment of reading skill. Their opinions about the assessment and evaluation applications presented in the teacher guidebook for reading skill and about assessment tools exactly corresponding to reading objectives are negative in general. They stated, in relation to teacher competencies, that a teacher should be able to ask questions to evaluate their students' reading comprehension. The problems they face in the assessment of reading skill were stated to be crowded classes and students having reading difficulties. They also stated that the number of students in classes should be reduced and the texts used should be revised.

The findings related to the assessment and evaluation in the dimension of listening/monitoring skill revealed that most of the teachers do not prepare assessment and evaluation tolls to assess listening/monitoring skill, those who are preparing such tools take great care to ask questions from the important parts of the text and they prefer open-ended and short-answer questions in the evaluation of listening/monitoring skill. Their opinions about the assessment and evaluation applications presented in the teacher guidebook for listening/monitoring skill and about assessment tools exactly corresponding to listening/monitoring objectives are negative in general and they do not use them. They stated, in relation to teacher competencies, that a teacher should be able to assess whether the student listen or not. The problems they face in the assessment of listening/monitoring were stated to be crowded classes, distracted attention of the student while listening, teachers' not being able to measure listening/monitoring skill and assessment's taking time. They stated that the number of students in classes should be reduced, the texts used should be revised and environment suitable for listening/monitoring should be created. However, in general, the opinions stated by the teachers showed that most of the teachers do not conduct listening/monitoring activities.

In light of the findings of the study, following suggestions can be made; for healthy assessment and evaluation to be conducted in relation to comprehension skills, the number of students in classes should be reduced, assessment tools can be diversified, in-service training can be given to teachers about assessment and evaluation, some criteria can be added to objectives in relation to assessment and evaluation and reading and listening/monitoring texts can be revised. 